\title{
Eptingiacea and Saturnaliacea (Radiolaria) from the middle Carnian of Turkey and some late Ladinian to early Norian samples from Oman and Alaska
}

\author{
Paulian Dumitrica • Ugur Kagan Tekin • \\ Yavuz Bedi
}

Received: 31 March 2009/Accepted: 25 September 2009/Published online: 31 October 2009

(C) Springer-Verlag 2009

\begin{abstract}
This article is a taxonomic study of the radiolarian species of the superfamilies Eptingiacea and Saturnaliacea occurring in the middle Carnian fauna from the Köseyahya section, near the town of Elbistan, southeastern Turkey. This fauna is characteristic of the Tetraporobrachia haeckeli Radiolarian Zone as defined in Austria and later found also in Turkey and Oman. It comes from an $8 \mathrm{~m}$ thick succession of clayey/cherty limestones from the lower part of the section. In addition, a few species from the late Ladinian and Carnian from Oman and the early Norian from Alaska have also been included in this study, in order to improve some generic diagnoses and to show the diversity and evolutionary trends of some genera. 32 radiolarian species of which 22 are new are described and illustrated, and assigned to 16 genera of which three are new (Capnuchospyris, Veleptingium, and Triassolaguncula). The diagnoses of some species, genera, subfamilies and families have been revised, and the family Eptingiidae has been raised to the rank of superfamily.
\end{abstract}

P. Dumitrica $(\square)$

Dennigkofenweg 33, 3073 Gümligen, Switzerland

e-mail: Paulian.Dumitrica@unil.ch

U. K. Tekin

Department of Geological Engineering,

Hacettepe University, 06532 Beytepe Ankara, Turkey

e-mail: uktekin@hacettepe.edu.tr

Y. Bedi

Department of Geological Research,

General Directorate of Mineral Research and Exploration, 06800 Canaya, Ankara, Turkey

e-mail: y.bedi@mta.gov.tr
Keywords Radiolaria $\cdot$ Eptingiacea $\cdot$ Saturnaliacea . Taxonomy · Triassic $\cdot$ Turkey · Oman · Alaska

Kurzfassung Diese Arbeit ist eine taxonomische Studie über die Arten der Superfamilien Eptingiacea und Saturnaliacea der Mittel-Karnium Radiolarienfauna aus Köseyahya, einer Lokalität östlich der Stadt Elbistan in der südöstlichen Türkei. Die Fauna entspricht der Tetraporobrachia haeckeli Zone, welche in Österreich definiert und später auch in der Türkei und im Oman gefunden wurde und stammt aus dem unteren Teil einer 8 Meter mächtigen Abfolge von mergelig/kieseligen Kalken. Daneben wurden auch einige Arten aus dem Ladin und dem Karnium aus dem Oman und aus dem unteren Norium aus Alaska in diese Studie aufgenommen, um einige generische Bestimmungen zu verbessern und die Diversität und die Entwicklungsrichtungen von einigen Genera aufzuzeigen. Es werden 32 Arten (davon 22 neue Arten) und 3 neue Gattungen (Capnuchospyris, Veleptingium und Triassolaguncula) beschrieben. Die Beschreibungen einiger Arten, Gattungen, Unterfamilien und Familien wurden überarbeitet und die Familie Eptingiidae in den Rang einer Superfamilie angehoben.

Schlüsselwörter Radiolaria · Eptingiacea ·

Saturnaliacea · Taxonomie · Trias · Türkei - Oman ·

Alaska

\section{Introduction}

In two previous articles Tekin \& Bedi (2007a, b) described most of the middle Carnian nassellarian radiolarians of the very well preserved and very diverse fauna occurring in the Köseyahya section of the Köseyahya Nappe from the 
eastern Taurides, southeastern Turkey. In this article, in order to make known the whole fauna, we describe all the genera and species of the superfamilies Eptingiacea and Saturnaliacea occurring in the region studied. Although these two superfamilies are rather distinct from each other there is an element that seems to connect them. This element is represented by the small and short ranging family Spongosaturnaloididae that, according to the hypothesis presented by Dumitrica \& Guex (2003), seems to represent Carnian eptingiids having acquired a ring by a horizontal gene transfer from the Saturnalidae.

The importance of the middle Carnian fauna from the Köseyahya section is not only its diversity but, especially, its excellent preservation that enables, for many species, knowledge of their innermost structures and, consequently, contributes to the building of a much more natural taxonomic system for the Triassic Spumellaria and Entactinaria.

\section{Geological setting and material}

Most of the radiolarians presented in this study come from the Köseyahya section, near the town of Elbistan, SE Turkey (Fig. 1, 1.1). This region includes many tectonic units, including Binboga metamorphics, Gülbahar nappe, Köseyahya nappe, and Ophiolite nappes (Bedi et al. 2005; Tekin \& Bedi 2007a, b). In this area the Köseyahya nappe consists mainly of clastic sediments at the base, overlain by radiolarian rich clayey and cherty limestones with marl and mudstone alternation, all of middle Carnian age. Higher up, ammonoid-bearing nodular limestones with tuff interlayers, overlain by "Hallstatt limestones" with abundant ammonoids are characteristic lithologies. The upper part of the nappe is composed of middle Upper TriassicLower Cretaceous neritic carbonates and calciturbidites. Finally, at the top of this nappe pyle, Upper Cretaceous pelagic cherty limestones are widely exposed (see Tekin \& Bedi 2007a for brief review).

The Köseyahya section is situated $1 \mathrm{~km}$ south of the village Köseyahya (L38 C2 quadrangle sheet, between 42.28.360 N/3.62.755 E and 42.28.484 N/3.62.872 E UTM coordinates) (Fig. 1, 1.2), and was measured along one of the slices of the Köseyahya nappe. Although the total thickness of the section is of about $118 \mathrm{~m}$ and 26 samples were taken along it, well-preserved radiolarians were only recovered from five samples (04-ELB-1, 04-ELB-2, 04ELB-3, 04-ELB-4, and 04-ELB-5; Fig. 2). These productive samples come from unit 2 consisting of an $8 \mathrm{~m}$ thick succession of cherty and clayey limestones overlying the unit 1 represented by an alternation of sandstones and marls (see Tekin \& Bedi 2007a, b for details of the section).

Besides nassellarians, most species of which have already been published (Tekin \& Bedi 2007a, b), the productive samples of the Köseyahya section contain many characteristic spumellarian and entactinarian taxa of the Middle Carnian Tetraporobrachia haeckeli Zone, for example: Tetraporobrachia haeckeli Kozur \& Mostler, Divatella austriaca Kozur \& Mostler, Weverella tetrabrachiata Kozur \& Mostler, Palaeosaturnalis hugluensis Tekin, Spongotortilispinus carnicus (Kozur \& Mostler), many species of Veghicyclia Kozur \& Mostler, Capnuchosphaera De Wever, Praeorbiculiformella Kozur \& Mostler, and many others, as

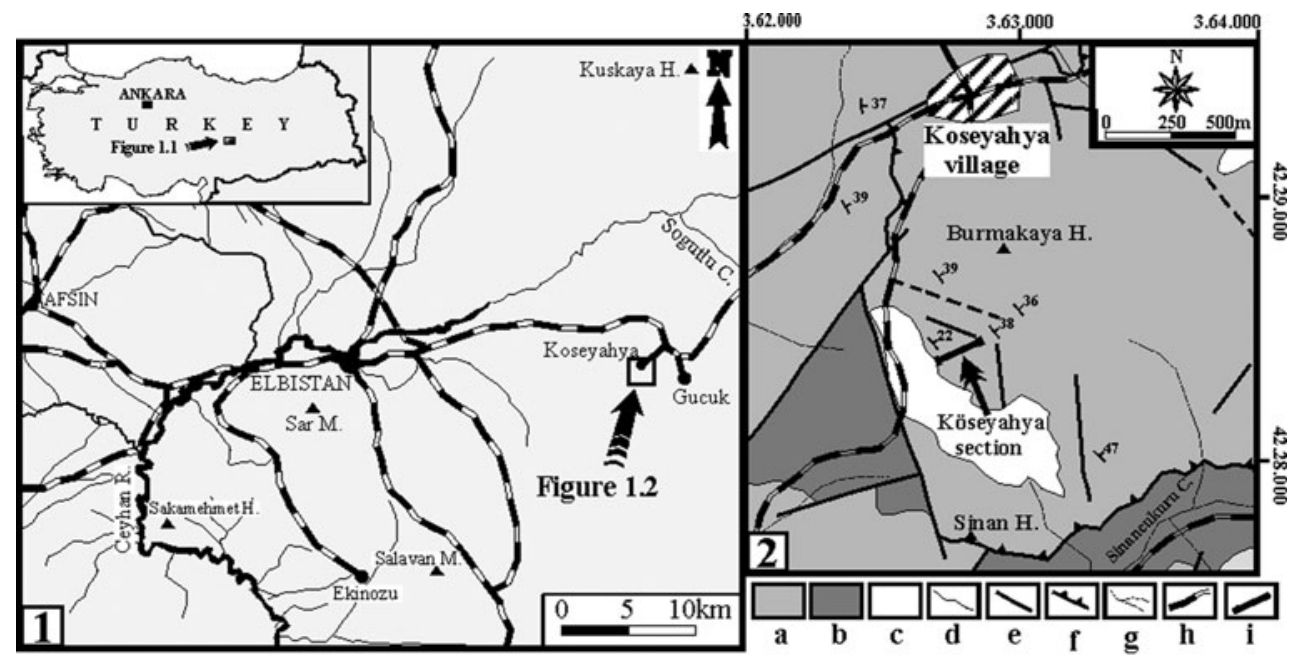

Fig. 1 Location and geological maps of the study area. 1.1. Geographic map showing the location of the study area; the inset rectangle indicates the location of Fig. 1.1. 1.2. Geological map of the study area indicating the location of the Köseyahya section (revised after Bedi 2004). Abbreviations: $a=$ Triassic to Early Cretaceous carbonates of the Köseyahya nappe, $b=$ Late Cretaceous pelagic sediments of the Köseyahya nappe, $c=$ post-Mesozoic rock units, $d=$ stratigraphic boundary, $e=$ fault, $f=$ thrust, $g=$ drainage system, $h=$ main roads, $i=$ location of the Köseyahya section 


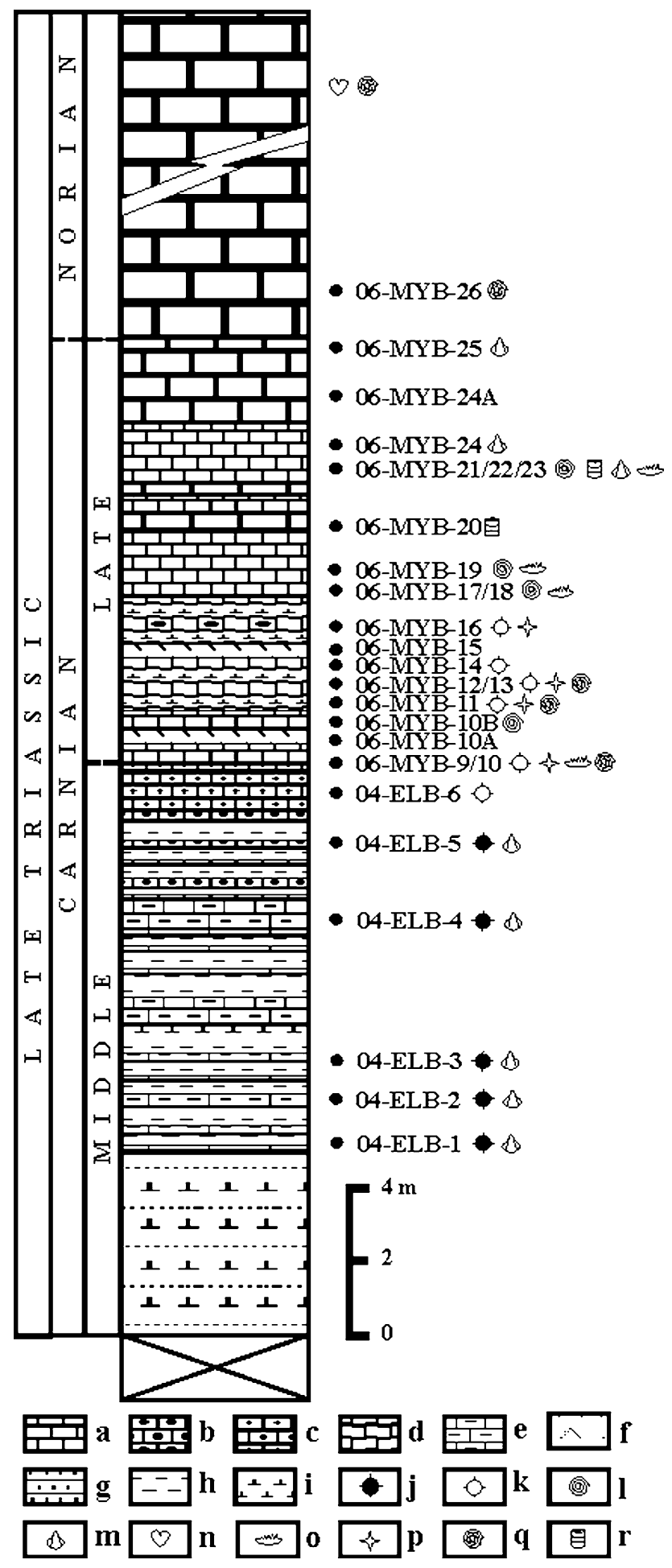

Fig. 2 Log of the Köseyahya section. Abbreviations: $a=$ Limestone, $b=$ Limestone with chert nodules, $c=$ Limestone with chert nodules and bands, $d=$ Nodular limestone, $e=$ Clayey limestone, $f=$ Tuff, $g=$ Sandstone, $h=$ Mudstone, $i=$ Marl, $j=$ Determinable Radiolaria, $k=$ Indeterminable Radiolaria, $l=$ Ammonoid, $m=$ Halobia, $n=$ Megalodont, $o=$ Conodont, $p=$ Sponge spicule, $q=$ Foraminifera, $r=$ Crinoid

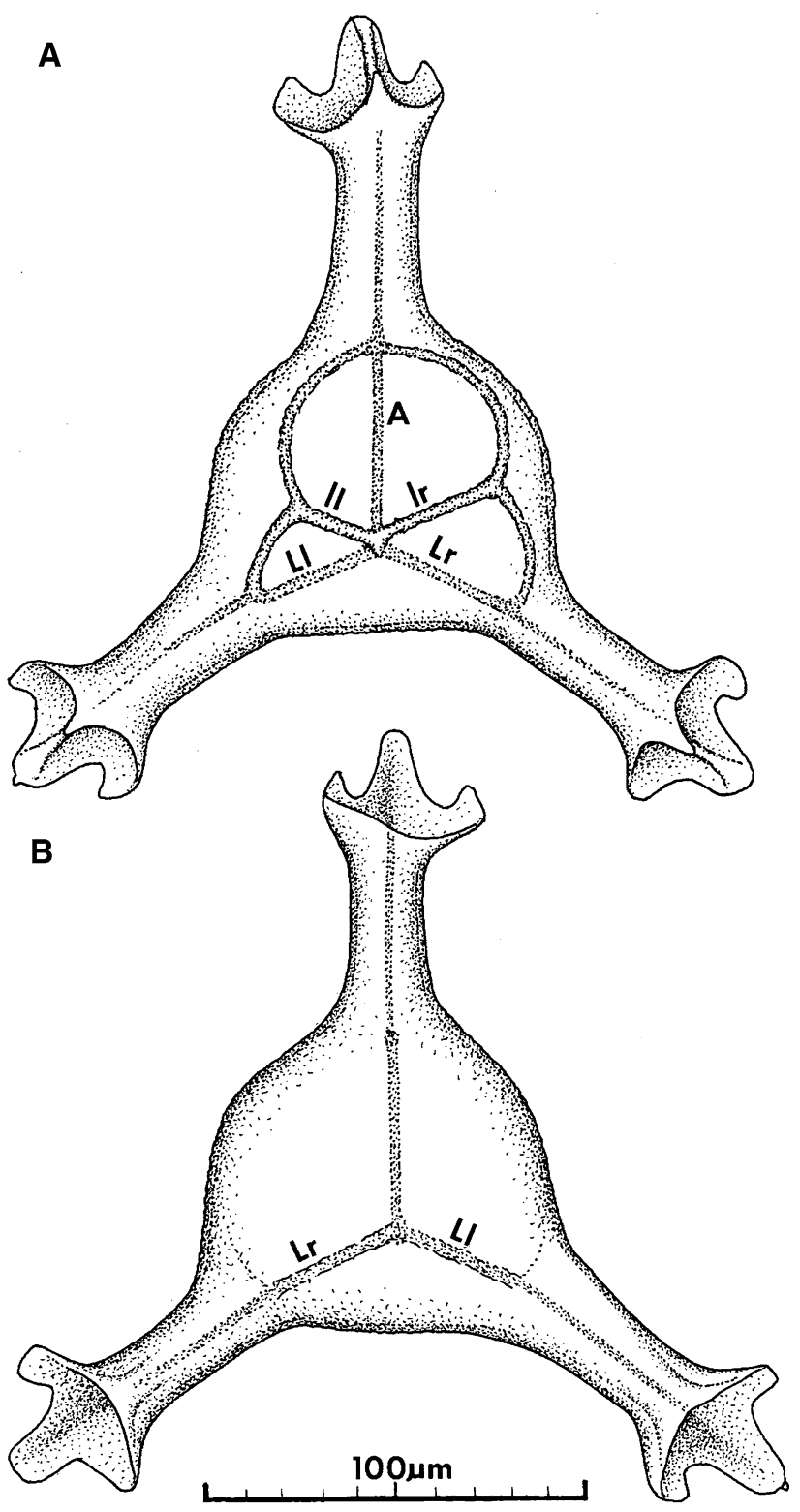

Fig. 3 Initial spicular system of Capnuchospyris capnuchosphaeroides Dumitrica \& Tekin n.sp. seen under optical microscope. a dorsal view, b ventral view. Notice that bars $A$ and $L$ go through the centre of the tubular spines. $A$ apical spine, $L_{1}$ left primary lateral bar, $L_{\mathrm{r}}$ right primary lateral bar, $l_{1}$ left secondary lateral bar, $l r$ right secondary lateral bar

we shall show in this paper and in future papers (in preparation). Compared with the radiolarian fauna of the same zone from Göstling and Großreifling in Austria (Kozur \& Mostler 1972, 1978, 1979, 1981; Lahm 1984) and the Huglu unit in Turkey (Tekin 1999), this association is much richer. It contains many new species and even genera (Elbistanium Tekin in Tekin \& Bedi 2007a, Capnuchospyris n. gen., Veleptingium n. gen., Triassolaguncula $\mathrm{n}$. gen., etc.) not yet 


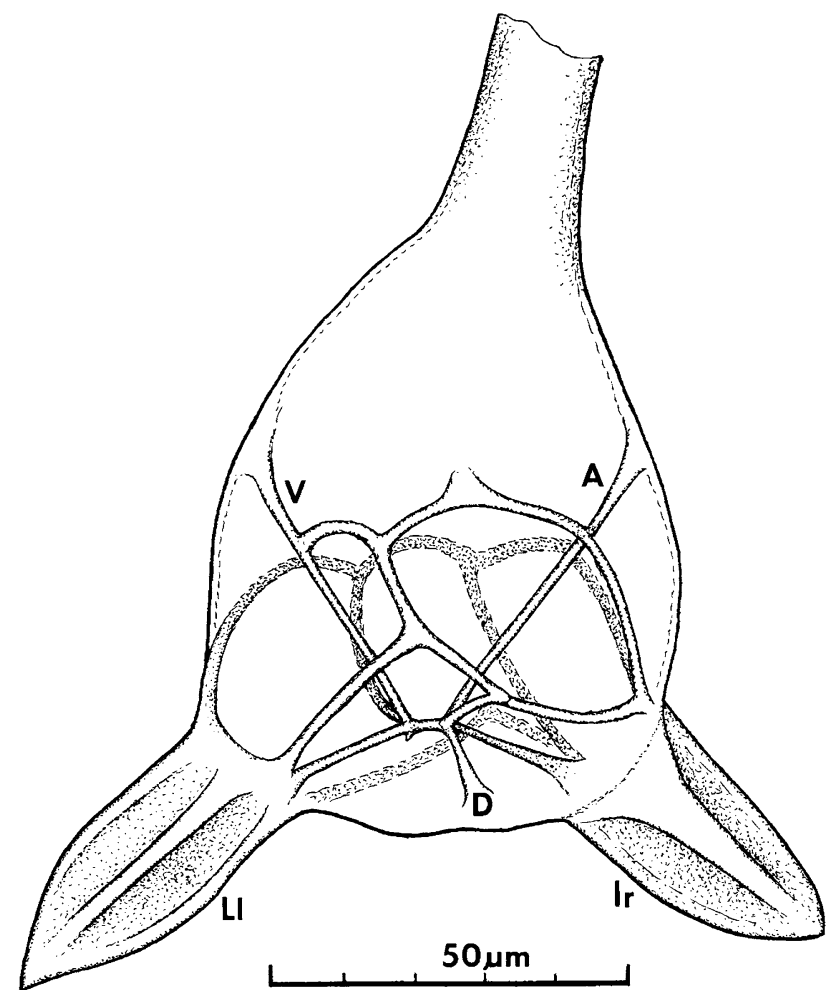

Fig. 4 Initial spicular system of Coronatubopyle spelae Dumitrica \& Tekin n.sp. in left lateral view. $A$ apical bar, $V$ ventral bar, $D$ dorsal bar, $L l$ left primary lateral spine, $l r$ right secondary lateral spine

reported in the previous studies. This suggests either a slightly younger level within this zone or, most probably, is a consequence of the very good preservation of this fauna and of its lower latitude location.

As regards the chronostratigraphic age of this fauna we follow Kozur \& Mostler (1994: pp. 40, 166) who considered it of Julian (middle Carnian) age, in the idea of subdivision of the Carnian into three substages. However, if the Carnian stage is subdivided into only two substages (Julian and Tuvalian), the Julian substage containing also the Cordevolian (Ogg 2004), the age of this fauna is late Julian.

\section{Additional samples}

In order to prove additional occurrences of some species or the diversity of some genera of the families studied we also included in this article a few specimens or species from four other localities outside Turkey, namely three from Oman and one from Alaska.

Zulla Formation, Al Jil section, Oman, UTM 50.35.00 $\mathrm{E} / 25.71 .500 \mathrm{~N}$

The section is located in the Oman Mountains, Wadi Al Ayn area, and geologically belongs to the Hamrat Duru

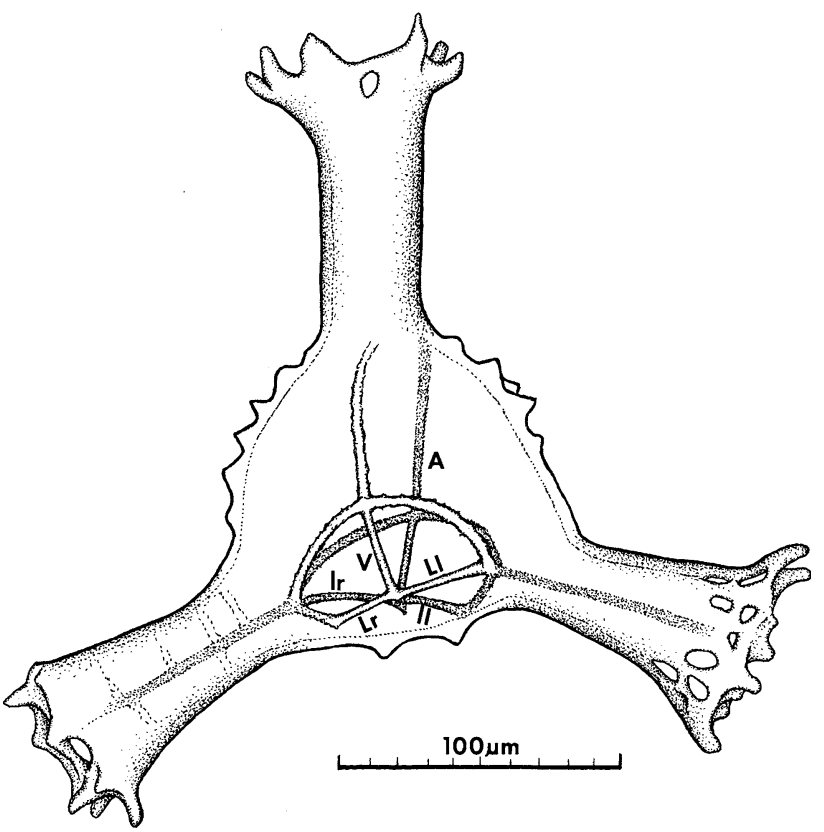

Fig. 5 Initial spicular system of Divatella austriaca Kozur \& Mostler in ventral view seen under optical microscope. $A$ apical bar, $V$ ventral bar, $L_{\mathrm{r}}$ right primary lateral bar, $L_{1}$ left primary lateral bar, $l_{\mathrm{r}}$ right secondary lateral bar, $l_{1}$ left secondary lateral bar

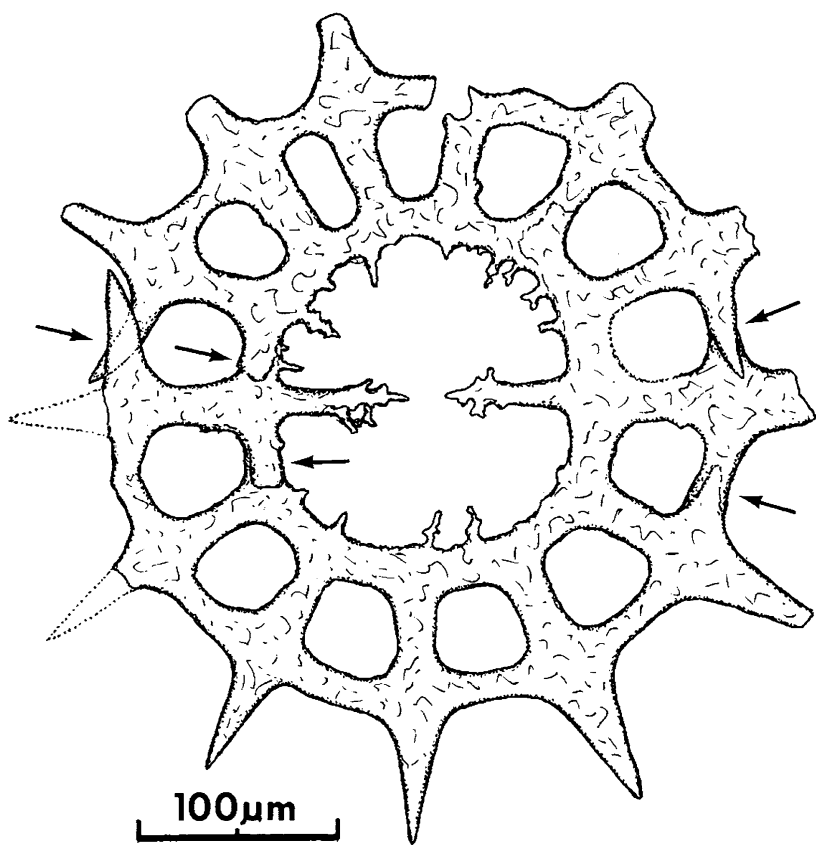

Fig. 6 Heliosaturnalis magnus Kozur \& Mostler, specimen broken during the skeletal growth, drawn after Fig. $15 \mathrm{~g}$. Arrows point to suture zones and to aborted connections

Group of the Hawasina Complex (Blechschmidt et al. 2004). It exposes the whole succession of the Zulla Formation and is also the type area of the Al Jil Formation of Béchennec (1987), which represents the chert member of 


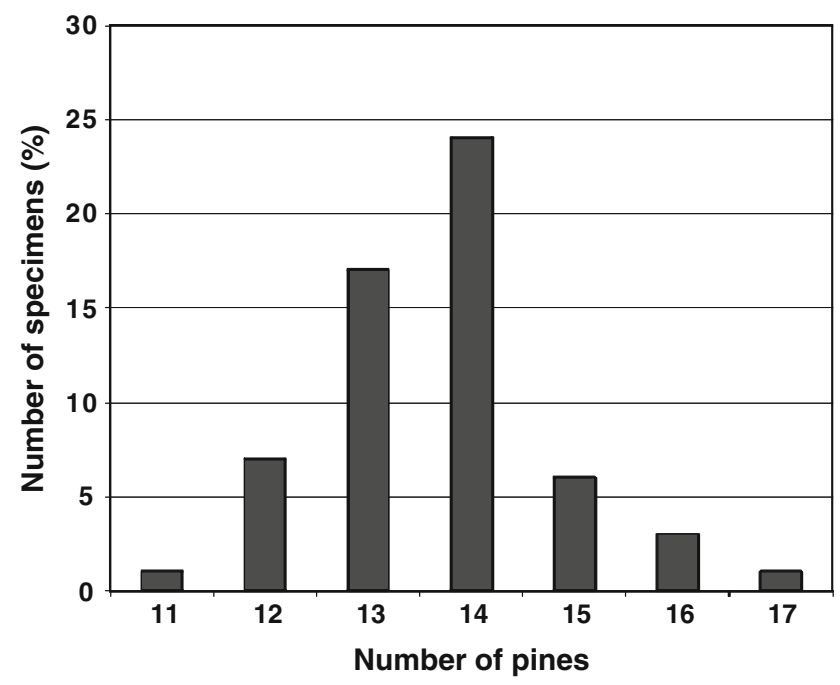

Fig. 7 Histogram based on 59 specimens showing the variability of the number of spines of Palaeosaturnalis hugluensis Tekin in the populations of the Elbistan samples

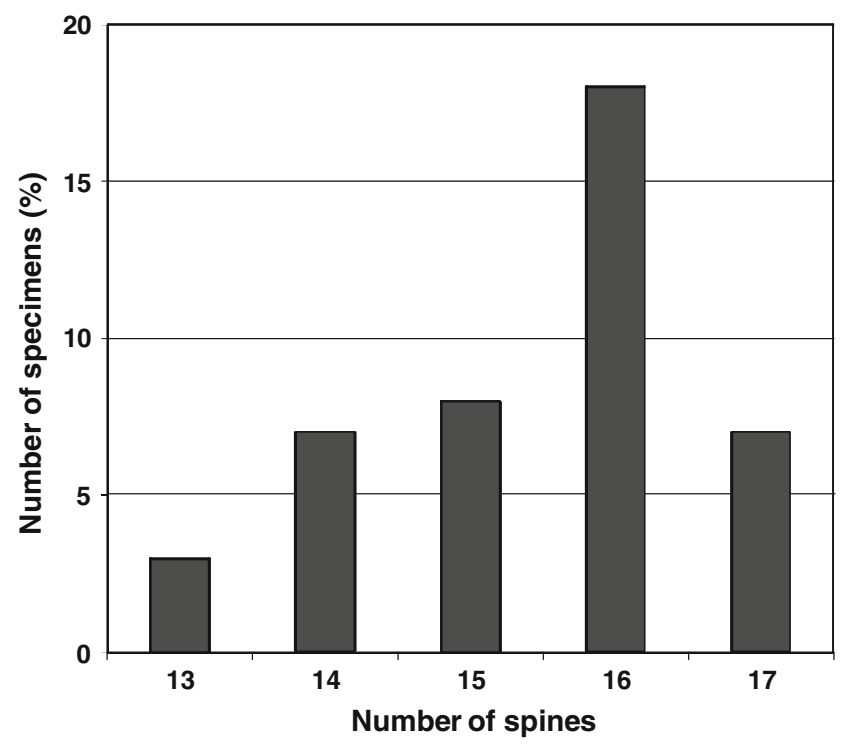

Fig. 8 Histogram based on 43 specimens showing the variability of the number of spines of Pseudoheliodiscus primitivus (Kozur \& Mostler) in the populations of the Elbistan samples

the Zulla Formation. The chert member is here about $70 \mathrm{~m}$ thick. Radiolarians are common to abundant, but their preservation is moderate to poor. A single sample (BR603) was used for this paper. This sample, collected at $57 \mathrm{~m}$ above the base of the measured section and $18 \mathrm{~m}$ above the first chert bed, is early Longobardian in age and belongs to the Muelleritortis firma Zone of Kozur (2003). This zone, which was not originally defined but just named, should contain the period from the first appearance of the nominal species to the FAD of $M$. cochleata. The sample is located

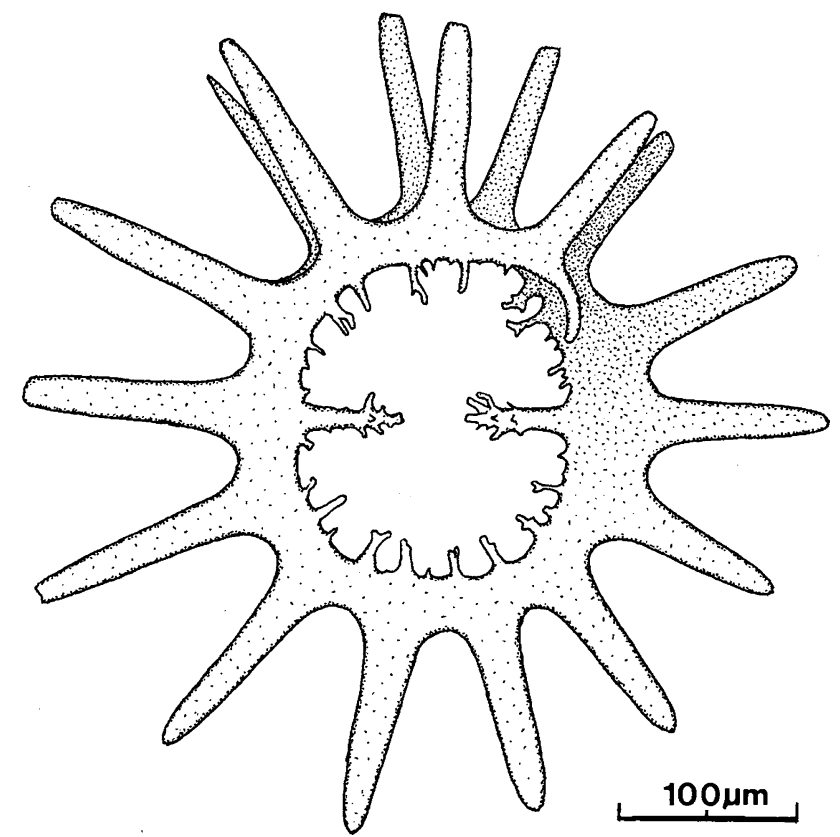

Fig. 9 Pseudoheliodiscus primitivus (Kozur \& Mostler) with open ring. Same as Fig. 16w

$3 \mathrm{~m}$ below the first appearance in the section of the species Muelleritortis cochleata (Nakaseko \& Nishimura), which marks the lower boundary of the M. cochleata Zone and contains: Baumgartneria curvispina Dumitrica, Bogdanella praecursor Kozur \& Mostler, Falcispongus cf. calcaneum Dumitrica, Muelleritortis firma (Gorican), Paroertlispongus daofuensis Feng \& Liang, Spongoserrula antiqua Kozur \& Mostler, etc.

Zulla Formation, Wadi Bani Khalid section, Oman, UTM 70.65.11 E/24.96.352 N

The section was described in Blechschmidt et al. (2004) and partly in Dumitrica \& Hungerbühler (2007). It is also located in the Oman Mountains and belongs to the Hamrat Duru Group of the Hawasina Complex. The section offers the best outcrop of the Radiolarian Chert Member of the Triassic Zulla Formation. In this section this member has a thickness of about $55 \mathrm{~m}$ and consists of thin-bedded, red and green radiolarian ribbon chert with interbedded siliceous shale. Its lower boundary is gradual and its top is marked by a coquina level with Halobia beyrichi Mojs. The chert member spans the late Anisian (Illyrian)—early Norian stratigraphic period. From this section we illustrated in this article a few species occurring in three samples (BR917, BR918 and BR919). The age of samples BR918 and BR919 is early Late Carnian corresponding to the Spongotortilispinus moixi Zone of Moix et al. (2007). The sample BR917 was taken a distance of $1.5 \mathrm{~m}$ below sample BR918. Biostratigraphically it lies between the 
Teraporobrachia haeckeli Zone and Spongotortilispinus moixi Zone and its age is probably early late Carnian (Dumitrica \& Hungerbühler 2007).

Haliw Formation, Hamadiyin I section, Oman, UTM 58.28.11 E/25.21.071 N

The section is located northwest of the Hamadiyin and Haliw villages, a few hundred meters north of the road Izki-Sinew, and exposes, from bottom to top, the two formations of the Umar Group of the Hawasina Complex: the Sini Formation composed mainly of volcanic rocks and the Haliw Formation (Glennie et al. 1974) or Aqil Formation (Béchennec et al. 1992). The latter formation is composed of Triassic-Cretaceous predominantly siliceous pelagic deposits and calcirudite and/or megabreccia with reworked shallow-marine carbonates. The Triassic portion exposed in this section is represented by its two lower members: the lower cherty limestone member (about $13 \mathrm{~m}$ ) of middle Carnian age and the filamentous red chert member (about $15 \mathrm{~m}$ ) with rare levels of filamentous limestone of late Carnian (Tuvalian) age. Sample HA4, which we used for this paper, was collected from the top of the lower member, $13 \mathrm{~m}$ above the base of the measured section.

\section{Glenn Shale Formation, east-central Alaska}

The Glenn Shale of east-central Alaska is composed of two distinct temporal stratigraphic entities of significantly differing origins: a lower portion consisting of a $200 \mathrm{~m}$ thick Middle to Upper Triassic marine carbonate unit recognized throughout east-central Alaska and an upper portion, 1,600 m thick, of Lower Cretaceous clastic flysch-like unit (Brabb 1969). The Triassic Glenn Shale of the area located between latitudes $65^{\circ} 00^{\prime}$ and $65^{\circ} 30^{\prime} \mathrm{N}$ and longitudes $141^{\circ} 00^{\prime}$ and $142^{\circ} 00^{\prime} \mathrm{W}$ was investigated by Robinson (1988) for the radiolarians studied in his unpublished Master of Science thesis at the University of Texas at Dallas. A portion of a residue of one sample was given by Robinson to Dr Spela Gorican who, in turn, gave it to the senior coauthor (PD) of this paper. The exact location of the sample in east-central Alaska is unknown; it is from one of the two sections measured by Robinson (Trout Creek or Michigan Creek). Radiolarians are very well preserved and according to Robinson belong to the Latium paucum subzone of the Capnodoce Zone of Pessagno et al. (1979) and Blome (1984) ranging from latest Carnian to early Norian.

\section{Taxonomic descriptions and discussions}

For better comparison, in almost all the figures accompanying this paper the specimens of Eptingiacea have been oriented, as far as possible, with the apical bar or spine directed upward. The Saturnaliacea have been oriented with the polar rays or spines in the horizontal plane because relative to the initial skeleton they represent, in fact, lateral spines (Dumitrica \& Zügel 2008: 57 col. 2).

\section{Class Radiolaria Müller 1858}

Subclass Polycystina Ehrenberg 1838, revised Riedel 1967

\section{Order Entactinaria Kozur \& Mostler 1982}

Superfamily Eptingiacea Dumitrica 1978, revised herein

Diagnosis: Usually three-spined Entactinaria with initial spicule of nassellarian type consisting commonly of bars MB, A, V, D, $\mathrm{L}_{\mathrm{r}}, \mathrm{L}_{1}, \mathrm{l}_{\mathrm{r}}, \mathrm{l}_{\mathrm{l}}$, and arches AV, $2 \mathrm{Ll}, 2 \mathrm{LV}$. Bars A and $2 \mathrm{~L}$, or one $\mathrm{L}$ and one 1 usually extended outside shell into three primary spines. Both bars 1 rarely extended outside test wall. Spines free or connected distally by a ring.

Remarks: We include in this superfamily the families Eptingiidae and Spongosaturnaloididae. Despite their different morphology, these two families have in common the same nassellarian type spicular system and the same cephalis-shaped skeleton. If we want to find a place of the superfamily Eptingiacea, as herein considered, in the phylogenetic tree of Radiolaria, we should place them somewhere near the monocyrtid Triassic Nassellaria. Both Nassellaria and Eptingiacea have probably a common ancestor. It is also possible that the Eptingiacea come from some Early Triassic monocyrtid Nassellaria, or, on the contrary, that the monocyrtid Nassellaria come from some primitive Eptingiacea (Spela Gorican, in litt.). The morphology and spicular structure of the Eptingacea is rather similar to that of the Cenozoic nassellarian superfamily Acanthodesmiacea or Spyridina. Both Eptingiacea and Acanthodesmiacea have usually a sagittal ring, a shell consisting only of a cephalis-shaped skeleton that commonly does not develop along an axis as in Cyrtida but in lateral directions forming flat skeletons (compare Perispyridium Dumitrica with Perispyris Haeckel or Nephrospyris Haeckel).

Range: Early Triassic to latest Jurassic (late Tithonian) so far as known.

\section{Family Eptingiidae Dumitrica 1978}

Type genus: Eptingium Dumitrica 1978: 33.

Diagnosis: Eptingiacea with spines not connected distally by a ring.

Remarks: This family comprises the following subfamilies:

Eptingiinae Dumitrica 1978 
Ferresiinae Carter 1993

Charlotteinae Whalen \& Carter, in Carter et al. 1998

Perispyridiinae Takemura 1986

Divatellinae Kozur \& Mostler 2006.

Remarks: The subfamily Ferresiinae (type genus Ferresium Blome 1984) comprises Norian to Rhaetian eptingiids with thick triangular spongy shell. Studies are necessary to prove if this subfamily, comprising only the type genus, can be retained or if it is a junior synonym of the subfamily Eptingiinae.

The subfamily Charlotteinae (type genus Charlottea Whalen \& Carter, in Carter et al. 1998) is a subfamily for which studies of their internal structure should be done to see if all the genera included in it have an internal spicule of the eptingiid type. Unpublished studies of internal structures made by the senior co-author and the figures of this structure published by Whalen \& Carter, in Carter et al. (1998: pl. 2 Figs. 8, 19 and, especially, pl. 2 Figs. 10, 11 representing a specimen that is not Poulpus (?) sp. but Charlottea sp.) show that the initial structure is similar to that of the Perispyridiinae, the two lateral spines being the prolongation of one bar L and one bar 1 of the spicule. This subfamily surely comprises the genera Charlottea Whalen \& Carter, in Carter et al. (1998) and Tozerium Whalen \& Carter, in Carter et al. (1998). The genus Thurstonia Whalen \& Carter, in Carter et al. (1998) is an angulobrachiid close to Loupanus CARTER and the same is probably Danubea Whalen \& Carter, in Carter et al. (1998), but the genus Sofia Whalen \& Carter, in Carter et al. (1998) seems to be a hagiastrid.

The subfamily Perispiridiinae (type genus Perispyridium Dumitrica 1978) comprises early to latest Jurassic taxa. It has its origin in the genus Charlottea Whalen \& Carter by the flattening of its test and the separation of the central part of the cortical test from the peripheral one. The central part becomes thinner-walled, loses the nodes, and builds also a cephalis-shaped test around the spicule. Charlottea sp. C of Whalen \& Carter, in Carter et al. (1998), and $C$. hottaensis Carter in Gorican et al. (2006) strongly suggest this trend. It is possible, therefore, that the subfamily Charlotteinae is a junior synonym of the subfamily Perispyridiinae.

The subfamily Divatellinae was erected by Kozur \& Mostler (2006) as an independent family from the family Eptingiidae. In our opinion, there is no reason to separate Divatella Kozur \& Mostler into another family. The genera Divatella, Carterella Kozur \& Mostler 2006, and Praedivatella Kozur \& Mostler 2006, are not sufficiently different from Pylostephanidium Dumitrica 1978 to be separated into another family. They only differ from the genera included in the family Eptingiidae by the development of the tube along one or all spines, an innovation initiated by the last genus, and follow the evolution of many other late Ladinian to Norian spumellarian and entactinarian radiolarians toward building hollow spines. We could, at most, separate them into a subfamily if we want to make subdivisions within the family Eptingiidae. This is what we did in this paper. Moreover, it is strange that Kozur \& Mostler (2006) included the family Divatellidae in the superfamily Palaeoscenidiacea, whereas the family Eptingiidae is included in the superfamily Hexastylacea, although both have the same spicular system and the same external morphology. Moreover, they considered, correctly, that one of the genera of the family Divatellidae (Carterella Kozur \& Mostler 2006) was derived from the genus Pylostephanidium Dumitrica, which is included in the family Eptingiidae. In this case it is difficult to understand how these two families could be assigned to different superfamilies. In fact, neither the family Eptingiidae nor the "family" Divatellidae seem to have anything in common with the two superfamilies. The family Eptingiidae with all the families and subfamilies mentioned above could very well constitute a superfamily.

Kozur \& Mostler (2006) included also the genus $\mathrm{Su}$ lovella Kozur \& Mock in the Divatellinae, but the reason they gave for this new assignment is dubious; the very small pores they mentioned on the tumidaspinae and that are visible on the two photographs of the holotype (Kozur \& Mostler 1981: pl. 47 Fig. 6; pl. 64 Fig. 2a, b) could be caused by corrosion, because the specimen is not very well preserved. By comparison with Capnuchosphaera carpathica Kozur \& Mock, which is surely a divatellin eptingiid and which shows this feature very well (some constrictions corresponding to arches) on the surface of its cortical shell (see discussion under Capnuchospyris $\mathrm{n}$. gen.), Sulovella constricta does not seem to show superficial constrictions.

\section{Subfamily Eptingiinae Dumitrica 1978}

Type genus: Eptingium Dumitrica 1978: 33.

Diagnosis: Eptingiidae with simple spines, without apical tube.

Remarks: If we want to make subdivisions within the family we think that the best character that we could take into account for the Triassic taxa is the presence or absence of an apical tube. We disagree on this point with Kozur \& Mostler (2006) who also included in this subfamily (family in their paper) two genera with apical tubes: Pylostephanidium Dumitrica and Coronatubopyle Kozur \& Mostler. It is true that the former genus had been originally included in this subfamily Dumitrica (1978), but at that time only the latest Anisian-early Ladinian and the late Jurassic genera were known. Moreover, since Divatella, the type genus of the subfamily Divatellinae, seems to have its 
origin in Pylostephanidium (Kozur \& Mostler, 2006), it is logical to consider Pylostephanidium the oldest representative of the subfamily Divatellinae.

We include in this subfamily the following genera: Cryptostephanidium Dumitrica 1978, Eptingium Dumitrica 1978, Spongostephanidium Dumitrica 1978, Triassistephanidium Dumitrica 1978, and Xenorum Blome 1984. It is possible that the genus Nodotrisphaera Kozur \& Mostler 2006 is also a member of this subfamily. Kozur \& Mostler (2006) included it, questionably, in the family Nodotetrasphaeridae Kozur \& Mostler and compared it with $P y$ lostephanidium, with which it has nodose spines in common.

Range: Early Triassic-Rhaetian.

\section{Genus Cryptostephanidium Dumitrica 1978}

1978 Cryptostephanidium n. gen. Dumitrica: 30.

Type species: Cryptostephanidium cornigerum Dumitrica 1978: 31.

Remarks: If in the lower Ladinian it is easy to distinguish this genus from the other eptingiid genera, and especially from Eptingium, this distinction is more difficult in the Carnian and lower Norian because of the diversification of all members of this family and the evolution of each genus. The genus Cryptostephanidium, as we consider it in this paper, contains species that should probably be assigned to Xenorum Blome. The difference between the two genera, if we refer to their type species, would be that in Cryptostephanidium the arch AV is not connected to the test wall and the arches Al are included in the test wall, whereas in Xenorum the arches are inside the test cavity and connected to the wall by a variable number of bars (see $X$. rotundum n.sp.).

Range: Middle Anisian to early Norian or younger. The early Norian, as upper limit of the range, is based on the species Betraccium irregulare Bragin (Bragin 2007), described from the Early Norian of Cyprus. This species does not belong to the genus Betraccium Blome but it is congenerical with the species described in this paper under Cryptostephanidium. It is for this reason that its pores are not so regular as in the Pantanelliidae to which Betraccium belongs.

\section{Cryptostephanidium dextrogyrum Dumitrica \& Tekin n.} sp. (Fig. 10a, b)

Description: Shell small, triangular with unequal sides, and with three three-bladed, dextrally twisted spines. Usually one side is slightly convex, another slightly concave, and the third straight. Wall with relatively large polygonal pores, irregular in size and arrangement and also in bar thickness. Spines three-bladed, relatively short, gently tapering distally and dextrally twisted about $180^{\circ}$ especially in the distal half. In proximal portion, their blades are usually divided longitudinally into secondary blades by a secondary groove.

Material: fifteen specimens.

Holotype: Fig. 10a, coll. Musée de Géologie Lausanne, No. 74405 .

Dimensions (in $\mu \mathrm{m}$, based on nine specimens): Length of sides of shell 61-79 (holotype 73), length of spines 5273 (holotype 73), proximal diameter of spines 21-34 (holotype 29).

Remarks: $C$. dextrogyrum n. sp. differs from the early Ladinian species $C$. cornigerum Dumitrica by having twisted and thicker spines and by having the blades of the spines subdivided proximally into two secondary blades by a secondary groove. Its spines partly resemble those of $C$. reticulospinosum n. sp., from which they differ in being shorter, dextrally twisted, and in not having a distal wartshaped protuberance. Also the pores of its shell are larger and the shell is about half as small as that of $C$. reticulospinosum n. sp.

Etymology: From its dextrally twisted spines (Latin dexter (dextra)—right and gyros_rounded).

Range and occurrence: Middle Carnian, Tetraporobrachia haeckeli Zone: Köseyahya section, east of Elbistan, Eastern Turkey; Zulla Formation, Wadi Bani Khalid, Oman.

Cryptostephanidium nannum Dumitrica \& Tekin n. sp. (Fig. 10c, d)

Description: Initial skeleton as with the genus. Test very small, triangular in face view, scalene, with three robust, pyramidal, and pointed spines at corners. Shell with 10-15 irregularly polygonal pores on each face separated by thin intervening bars. Blades of spines with a shallow secondary groove of variable length.

Material: five specimens in samples 04-ELB-1 and 04ELB-2.

Holotype: Fig. 10c, Musée de Géologie Lausanne, No. 74406.

Dimensions (in $\mu \mathrm{m}$, based on three specimens): Diameter of central shell 63-80 (holotype 63), length of spines 60-63 (holotype 62).

Remarks: Structurally and morphologically this new species resembles $C$. dextrogyrum n. sp., from which it differs especially in having straight spines.

Etymology: From the Greek nannos-dwarf.

Range and occurrence: Middle Carnian, Tetraporobrachia haeckeli Zone; Köseyahya section, Elbistan, SE Turkey. 


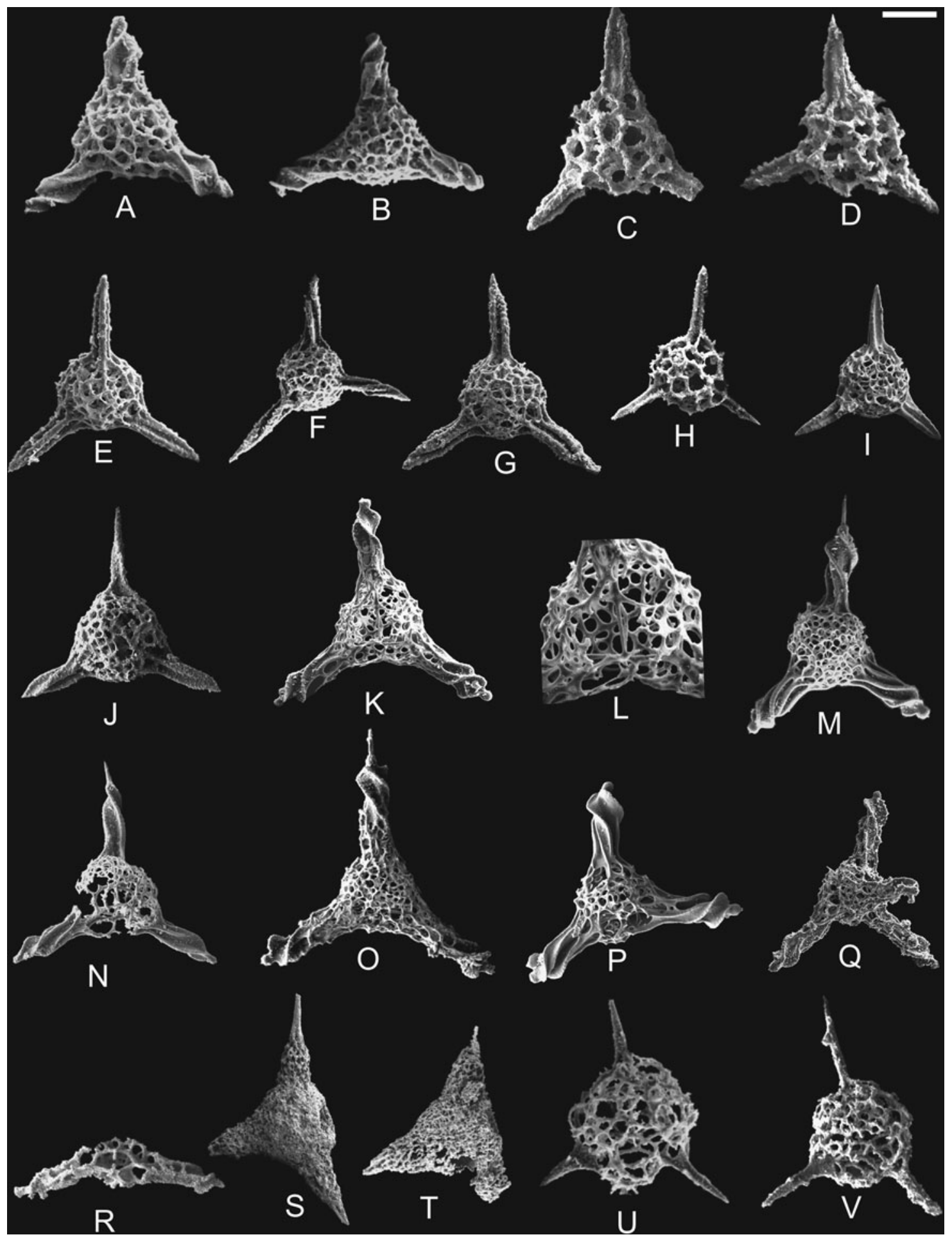

Fig. 10 a, b Cryptostephanidium dextrogyrum Dumitrica \& Tekin $\mathrm{n}$. sp.; a holotype, 04-ELB-1; b paratype, 04-ELB-1; scale bar for both specimens $=50 \mu \mathrm{m}$. c, d Cryptostephanidium nanum Dumitrica \& Tekin n. sp.; c holotype, 04-ELB-1; d paratype, 04-ELB-2; scale bar for both specimens $=40 \mu \mathrm{m}$. $\mathbf{e}-\mathbf{j}$ Cryptostephanidium rectospina Dumitrica \& Tekin n. sp.; e holotype, 04-ELB-1, scale bar $=70 \mu \mathrm{m}$; f-j paratypes: f 04-ELB-1; g 04-ELB-2; h, i 04-ELB-1; j 04-ELB-2; scale bar $=60,90,50,70$ and $70 \mu \mathrm{m}$, respectively. k-r Cryptostephanidium reticulospinosum Dumitrica \& Tekin n. sp.; $\mathbf{k}, \mathbf{l}$. holotype, 04-ELB-1; 1 detail of the initial spicule, scale bar $=100$ and $50 \mu \mathrm{m}$, respectively. $\mathbf{m}-\mathbf{r}$ paratypes: $\mathbf{m}-\mathbf{o} 04-E L B-1 ; \mathbf{n}$ corroded specimen showing the inner arches; p-q 04-ELB-2; $\mathbf{q}$ anomalous specimen with an additional spine; $\mathbf{r}$ fragment in apical view showing the $L$ bars and spines, the $V$ bar and the arches LV, BR914; scale bar for all specimens $=100 \mu \mathrm{m}$. t, $\mathbf{u}$ : Eptingium aljilense Dumitrica \& Tekin n. sp.; t holotype; u paratype; both from BR603, scale bar $=160 \mu \mathrm{m}$. u, v Spongostephanidium spongiosum Dumitrica; u 04-ELB-1; v 04-ELB-2; scale bar for both figures $=50 \mu \mathrm{m}$ 
Cryptostephanidium rectospina Dumitrica

\& Tekin n. sp. (Fig. 10e-g, h?, i, j)

Description: Shell relatively large, rounded triangular to globose with three pointed spines. Length of spines longer than ray of shell and slightly shorter than diameter of shell. Spines three-bladed, pointed, straight or slightly dextrally or sinistrally twisted, and practically equal with the same specimen and equally spaced. Shell wall with relatively dense polygonal pores of irregular size and arrangement. Intervening bars very variable in thickness.

Material: More than 20 specimens of which six are illustrated.

Holotype: Fig. 10e, Musée de Géologie Lausanne, No. 74407.

Dimensions (in $\mu \mathrm{m}$, based on eleven specimens): Diameter of central shell 61-148 (holotype 100), length of spines 58-148 (holotype 100).

Remarks: Although the type of spines (straight, dextrally or sinistrally twisted) is generally a species character, this species seems to show certain variability. Besides frequent specimens with straight spines there are rare specimens with slightly sinistrally twisted spines and very rare specimens with one or two dextrally twisted spines.

Etymology: From the Latin rectus-straight and spina-spine.

Range and occurrence: Middle Carnian, Tetraporobrachia haeckeli Zone; Köseyahya section, Elbistan, SE Turkey.

\section{Cryptostephanidium reticulospinosum Dumitrica}

\& Tekin n. sp. (Fig. 10k-r)

Description: Shell large, globular to triangular in face view, with some invaginated portions along some arches. Pore of test large, polygonal, circular or oval, and irregular in size and arrangement. Sagittal ring free inside the shell, but some arches of the initial skeleton interconnected to shell wall by some apophyses. Spines threebladed, about as long as test diameter. They have parallel borders on about two-thirds of their length and are slightly sinistrally twisted on that portion, but distal parts of spines are strongly sinistrally twisted. Distal ends of spines usually bear a wart-shaped protuberance, which may have a very thin shaft. Blades divided into two secondary blades by a secondary groove. Blades sometimes interconnected by transverse bridges giving the spines a reticulate aspect.

Material: About 50 specimens.

Holotype: Fig. 10k, 1, Musée de Géologie Lausanne, No. 74408.

Dimensions (in $\mu \mathrm{m}$, based on 19 specimens): Diameter of central shell without spines 100-163 (holotype 145), length of spines 136-197 (holotype 160), diameter of spines 37-60 (holotype 58).

Remarks: This species shows a very wide variability of the three spines, especially of their length and morphology of distal part, which can have a well-marked wart or, rarely, none, in which case the spines taper gently on the distal third and twist less fast. Extremely rare, anomalous specimens may have a fourth spine (Fig. 10q) disposed obliquely on the plane of the three spines.

Etymology: From the reticulate proximal part of spines.

Range and occurrence: Middle Carnian, Tetraporobrachia haeckeli Zone: Köseyahya section, Elbistan, SE Turkey; late Ladinian (Muelleritortis cochleata Zone, Spongoserrula rarauana Subzone) to early late Carnian (Spongotortilispinus moixi Zone) of Zulla Formation (Wadi Bani Khalid, Wadi Al Ayn, Al Jill), Oman.

\section{Genus Eptingium Dumitrica 1978}

1978 Eptingium n. gen. Dumitrica: 33.

Type species: Eptingium manfredi Dumitrica 1978: 33.

Remarks: The new species (Eptingium aljilense Dumitrica \& Tekin) herein described under this genus would prove that the generic features of the genus Eptingium are those mentioned in the original definition, for example: spicules and arches completely inside shell cavity, spines at various angles, and presence of an aperture within the interradial area between the apical and one of the lateral spines. On the holotype of the type species, the aperture is located on the right side of the test, between the apical spine and the right lateral spine. Unfortunately, we do not know whether this position is the same in all species of the genus Eptingium. Another character of the genus should be the larger size of specimens.

Range: Middle Anisian to late Ladinian or younger.

Eptingium aljilense Dumitrica \& Tekin n. sp.

(Fig. 10s, t)

Description: Test large with inflate central part and three arms at unequal angles $\left(100^{\circ}, 110^{\circ}\right.$, and $150^{\circ}$ on the holotype). Central test with a wide lateral aperture in the widest interradial area. Spines consisting of two portions: on the proximal half they are latticed, conical, with nodose surface and pores disposed irregularly or in irregular oblique rows; on the distal half they are pointed, threebladed proximally, and circular in cross-section distally. Shell of central shell with rough or slightly nodular surface and numerous small and irregularly distributed pores. Boundary between shell and latticed part of spines wellmarked by a change in contour. Spicule not known because of poor preservation but should be similar to that of the type species. 
Material: 25 specimens, all in the type sample.

Holotype: Fig. 10s, Musée de Géologie Lausanne, No. 74409.

Dimensions (in $\mu \mathrm{m}$ based on three specimens): Diameter of the central shell without spines 415-465 (holotype 465), length of spines 67-150 (holotype 150).

Remarks: Eptingium aljilense n. sp. resembles E. manfredi by its size and shape, from which it differs in having the proximal half of spines covered with cortical shell and the distal half simple, partly three-bladed, partly conical. The proximal half of its spines resembles also the spines of $\mathrm{Ve}$ leptingium odoghertyi $\mathrm{n}$. sp., a genus and species that probably derived from this new species by reduction of the distal half of the spines and disappearance or closing of the aperture.

Etymology: From the locality Al Jil, Oman, its type locality.

Range and occurrence: Early late Ladinian, Muelleritortis firma Zone, Zulla Formation, Oman.

Genus Spongostephanidium Dumitrica 1978

1978 Spongostephanidium Dumitrica: 32.

Type species: Spongostephanidium spongiosum Dumitrica 1978: 32.

Range: Early Triassic-late Triassic (Carnian) so far as known.

Spongostephanidium spongiosum Dumitrica 1978

(Fig. 10u, v)

1978 Spongostephanidium spongiosum Dumitrica: 32, pl. 2 Figs. 2-5.

2005 Spongostephanidium spongiosum Dumitrica. Gorican et al.: pl. 2 Fig. 8.

Remarks: The species is very rare in the Elbistan samples. Because of the very long range of the species, it is possible that the specimen illustrated belongs to a new taxon but we do not know how to separate it morphologically from the type species. Anyway, the morphological differences between it and the topotypes of $S$. spongiosum are very small.

Range and occurrences: Middle Anisian to late Carnian: Eastern Carpathians, Romania; Recoaro (Vicentinian Alps) and Marmolada Massif, Italy; Croatia; Zulla Formation, Wadi Bani Khalid, Oman; Köseyahya section, Elbistan, SE Turkey.

Genus Xenorum Blome 1984

1984 Xenorum n. gen. Blome: 45.

Type species: Xenorum largum Blome 1984: 45.

Remarks: This genus seems to be a junior synonym of Cryptostephanidium from which it appears to differ in only having twisted spines and the arches of the spicule inside test cavity. The shell of the two species (X. flexum Blome and X. largum Blome) (Blome 1984) resembles the shell of C. verrucosum Dumitrica in having nodes at pore frame vertices. The inner structure of the genus is unknown, but it seems to be rather similar to that of Cryptostephanidium (see discussion under the latter genus). Blome (1984) mentioned and vaguely illustrated remains of an internal spicular system but did not describe it and, although he compared Xenorum with Eptingium, he did not recognize its eptingiid affinities because he included it in the incertae sedis group. Because no study of its inner skeleton has yet been conducted, we continue using this genus for the new species we describe below.

Range: Middle Carnian to early Norian.

Xenorum rotundum Dumitrica \& Tekin n. sp. (Fig. 11a, b)

Description: Test globular, flattened in face view with three spines aligned with apical and primary lateral rays of the initial spicule. Spines equal, pointed, three-bladed, twisted dextrally about $360^{\circ}$ starting from the base, and gradually decreasing in diameter distally. Test wall with rather irregular pores. Initial skeleton with arches situated in the shell cavity. Arches connected to shell wall through one or two connecting bars.

Material: Two specimens, one from the Köseyahya section in Elbistan, SE Turkey, the other one from the sample BR919, Zulla Formation, Wadi Bani Khalid, Oman.

Holotype: Fig. 11a, Musée de Géologie Lausanne, No. 74410 .

Dimensions (in $\mu \mathrm{m}$, based on two specimens): Diameter of central shell 73-83 (holotype 83), length of spines 73103 (holotype 103), diameter of spines at the base 27-31 (holotype 31).

Remarks: Externally, this new species resembles very much $X$. flexum Blome in having a circular shell and conical, dextrally twisted, pointed spines but differs from it especially in being twisted on the whole length, whereas the spines of $X$. flexum are not twisted on the proximal third.

Range and occurrence: Very rare in the middle Carnian, Tetraporobrachia haeckeli Zone, Köseyahya section, Elbistan, SE Turkey, and early Late Carnian, Spongotortilispinus moixi Zone, Zulla Formation, Wadi Bani Khalid section, Oman.

Subfamily Divatellinae Kozur and Mostler 2006, emended herein

Type genus: Divatella Kozur \& Mostler 1981: 75.

Emended diagnosis: Eptingiidae with apical tube, with or without tubes aligned along lateral spines. Lateral spines 


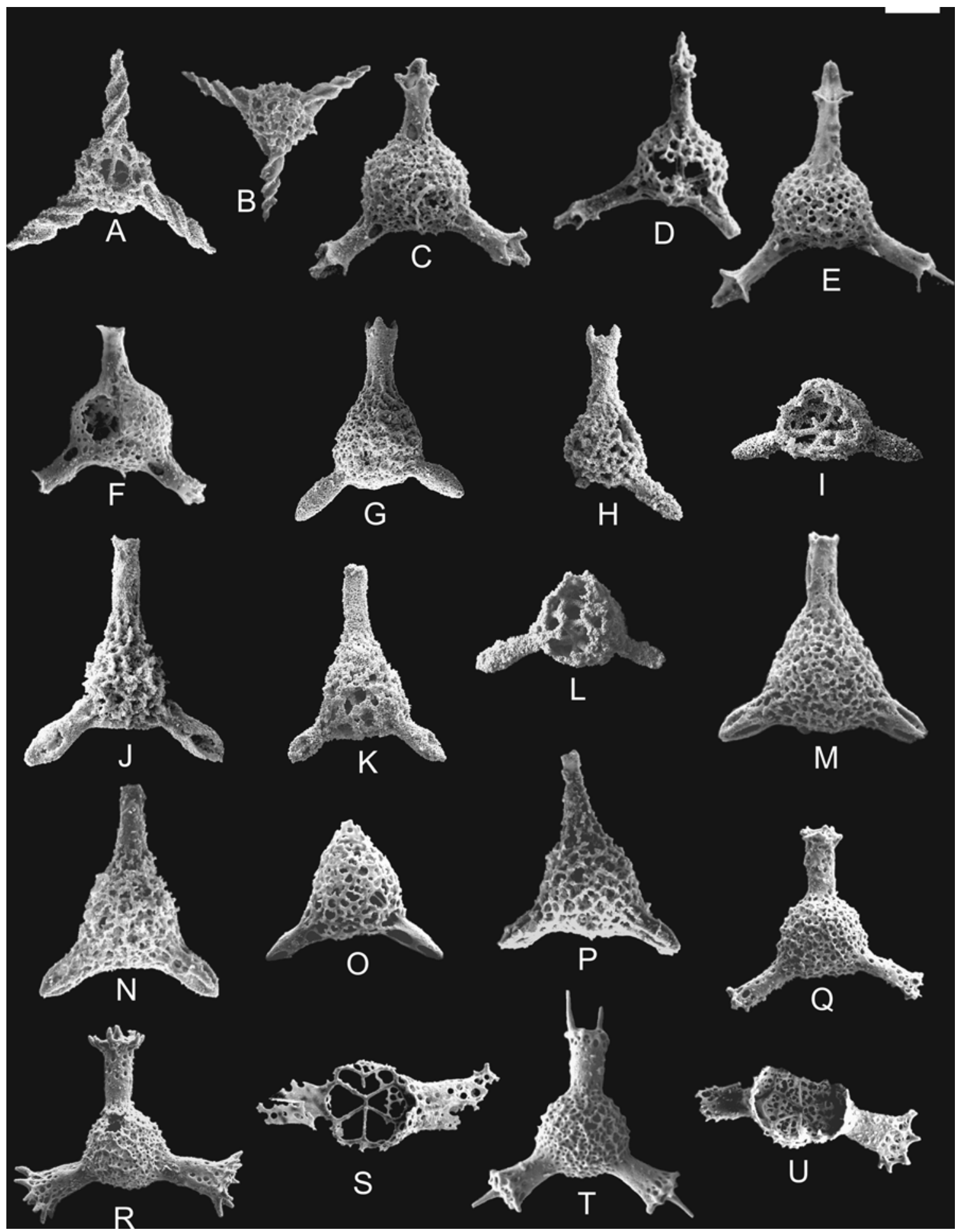

Fig. 11 a, b Xenorum rotundum Dumitrica \& Tekin n. sp.: a holotype with part of wall broken off showing the initial spicule and arches, BR919; b paratype, 04-ELB-2; scale bar for both specimens $=60 \mu \mathrm{m}$. c-f Capnuchospyris capnuchosphaeroides Dumitrica \& Tekin n. sp.; c holotype, 04-ELB-2; d-f paratypes; d specimen with part of wall broken off showing the initial spicule, 04-ELB-2; E, F. 04-ELB-1; scale bar for all specimens $=50 \mu \mathrm{m}$. $\mathbf{g}-\mathbf{i}$ Coronatubopyle denticulata Dumitrica \& Tekin n. sp.; g holotype, BR918; h, i paratypes; h BR919; i HA4; scale bar for all figures $=60 \mu \mathrm{m}$.
Coronatubopyle omanensis Dumitrica \& Tekin n. sp.: j holotype, BR918; k, l paratypes; k BR918; l. broken specimen, apical view showing the spicule and arches, compare with Fig. 4; BR919; scale bar for all figures $=70 \mu \mathrm{m}$. $\mathbf{m}-\mathbf{p}$ Coronatubopyle spelae Dumitrica \& Tekin n. sp.: m holotype, 04-ELB-1; n-p paratypes; n 04-ELB-2; $\mathbf{o}, \mathbf{p}$ 04-ELB-1; scale bar for all specimens $=50 \mu \mathrm{m} . \mathbf{q}-\mathbf{u}$ Divatella austriaca Kozur \& Mostler, 04-ELB-1; s, u apical view, specimens with apical part broken off showing the spicule and arches; scale bar $=80,80,60,90$, and $60 \mu \mathrm{m}$, respectively 
commonly aligned with one primary lateral bar and one diagonally opposite secondary lateral bar or arising from the middle of the arches Ll. Sagittal ring usually incompletely formed because of the absence of the arch AV or its incomplete closure.

Remarks: We emend herein the subfamily to include in it all the eptingiid genera with apical tube. We consider that this is the most important distinctive character of the subfamily, the more so because it is accompanied by the frequent absence of the arch $\mathrm{AV}$ and the change of the position of one lateral spine relative to the elements of the initial spicule. Consequently, as mentioned under the subfamily Eptingiinae, we also include in this subfamily the genus Pylostephanidium Dumitrica, which, in agreement with Kozur \& Mostler (2006), is considered as the forerunner of the subfamily, and the genus Coronatubopyle Kozur \& Mostler.

In our opinion the subfamily should comprise the following genera: Capnuchospyris n. gen., Coronatubopyle Kozur \& Mostler, Divatella Kozur \& Mostler, Pylostephanidium Dumitrica, Veleptingium n. gen., and probably Sulovella Kozur \& Mock and Tauridastrum Tekin. On the status of Sulovella we discussed under the family Eptingiidae. Its systematic position can be only solved by an investigation of its internal structure. If it really is a divatellin, it should have some remains of the initial spicule. As concerns Tauridastrum, it has an apical tube with an eccentric spine in the wall of the tube exactly as with Pylostephanidium, but it has a globose test with 5-10 long and thin, needle-like spines extending out in all directions. Although the internal structure is unknown, the fact that the spines do not extend radially but usually at different angles and that the prolongation of their directions towards the interior of the shell indicates an eccentric branching point would suggest the presence of an eccentric spicule.

Range. Latest Anisian or early Ladinian to early Norian.

Genus Capnuchospyris Dumitrica \& Tekin n. gen.

Type species: Capnuchospyris capnuchosphaeroides $\mathrm{n}$. $\mathrm{sp}$.

Diagnosis: Capnuchosphaera-like eptingiids with three tumidaspinae and an initial skeleton with $\mathrm{MB}, \mathrm{A}, \mathrm{V}$, a very short $\mathrm{D}$, two $\mathrm{L}$, two 1 , and arches $\mathrm{AV}, \mathrm{Al}, \mathrm{Ll}$, and $\mathrm{VL}$. Initial and cortical skeletons bilaterally symmetrical with sagittal ring in the plane of symmetry. Arches AV, VL, Al, and $\mathrm{Ll}$ included in the test wall. Spines $\mathrm{A}$ and the two $\mathrm{L}$ prolonged along the centre of tumidaspinae. Tumidaspinae with spinal tumour.

Remarks: This genus resembles so perfectly some species of the genus Capnuchosphaera De Wever and especially C. theloides De Wever, with which it can be easily confounded. In fact one of the species that we consider as belonging to this new genus-Capnuchosphaera carpathica
Kozur \& Mock (in Kozur \& Mostler 1981)—has already been described under the Capnuchosphaeridae and only recently was considered an eptingiid (divatellid according to Kozur \& Mostler 2006). What distinguishes externally this new genus from Capnuchosphaera is the inequality of the three sides of the central test, one side (the basal one) being straight whereas the other two are convex as an external reflection of the initial spicule. The genus Capnuchospyris $\mathrm{n}$. gen. resembles the genus Divatella Kozur \& Mostler in having tumidaspinae, but with Divatella the apical tube is completely hollow, without a central spine, and its apical spine is included in the wall of the apical tube. Also, with Divatella the tubular spines are almost never equal, the apical one being usually thicker whereas with Capnuchospyris they are equal and resemble perfectly the tumidaspinae of some Capnuchosphaeridae.

Etymology: From the Greek kapnuchos-chimney and spyris—ring. Feminine gender.

Range and occurrence: Middle Carnian to early Norian: Köseyahya section, Elbistan, SE Turkey; West Carpathians.

\section{Capnuchospyris capnuchosphaeroides Dumitrica} \& Tekin n. sp. (Figs. 3, 11c-f)

Description: Test small, bilaterally symmetrical, globular, rounded triangular in face view with basal side straight and the two lateral sides convex. Wall with small, rounded pores and rough surface because of some higher pore frames. Arches AV, VL, Al, and, $\mathrm{Ll}$ included in test wall and sometimes visible on the surface of test by slight constrictions. Arch AV fused to apical spine at the base of apical tumidaspina. Tumidaspinae with imperforate spinal tunnel, which usually decreases slightly in diameter distally. Spinal tumours with three three-bladed, petalshaped, and blunt lateral projections and a relatively short, blunt three-bladed spinal shaft, which in very-well preserved specimens can have a small and very thin axial spine.

Material: 25 specimens.

Holotype: Fig. 11c, Musée de Géologie Lausanne, No. 74411.

Dimensions (in $\mu \mathrm{m}$, based on five specimens): Height of shell without tumidaspinae 81-93 (holotype 84), length of tumidaspinae 70-93 (holotype 84).

Remarks: Capnuchospyris capnuchosphaeroides $\mathrm{n}$. sp. resembles the early Norian species Capnuchosphaera carpathica Kozur \& Mock (in Kozur and Mostler 1981, p. 74, pl. 48, Fig. 5), a member of this genus, from which it differs in not having long distal spinal shafts and in having shorter petal-shaped projections at the spinal tumours.

Etymology: From its resemblance with Сарпиchosphaera. 
Range and occurrence: Middle Carnian, Tetraporobrachia haeckeli Zone, Köseyahya section, Elbistan, SE Turkey.

Genus Coronatubopyle Kozur \& Mostler 2006

2006 Coronatubopyle n. gen. Kozur \& Mostler: 42.

Type species: Coronatubopyle coronata Kozur \& Mostler 2006: 42.

Remarks: We include in this genus all eptingiid species with an apical tube, with or without a distal crown, and the two lateral spines without nodes. The genus has so far been known only from the late Ladinian sample from Fojnica, Bosnia-Herzegovina, from where two species (C. coronata Kozur \& Mostler and C. robusta Kozur \& Mostler) have already been described (Kozur \& Mostler 2006). The lateral spines of these species have simple blades with open grooves. We describe herein also some species with the grooves between blades partly or completely covered, not only from the Julian fauna from Turkey but also from the Tuvalian fauna from Oman to show the evolutionary trends of the genus toward closing the grooves externally.

Range: Late Ladinian to late Carnian.

\section{Coronatubopyle denticulata Dumitrica \& Tekin n. sp.}

(Fig. 11g-i)

Description: Shell small, triangular to ovate with one apical tube and two lateral spines. Apical tube usually imperforate, cylindrical to slightly increasing in diameter distally with two or three distally directed teeth. Lateral spines longovate to spindle-shaped and closed distally. Shell wall rough-surfaced with irregular pores.

Material: seven specimens.

Holotype: Fig. 11g, Musée de Géologie Lausanne, No. 74412.

Dimensions (in $\mu \mathrm{m}$, based on three specimens): Height of the test without apical tube 87-114 (holotype 89), breadth of test without lateral spines 80-114 (holotype 80), length of lateral spines 63-108 (holotype 89), length of apical tube 5670 (holotype 56), diameter of lateral spines 24-31 (holotype 24); diameter of apical tube at the base 24-31 (holotype 24).

Remarks: Coronatubopyle denticulata $\mathrm{n}$. sp. resembles very much $C$. omanensis $\mathrm{n}$. sp. from which it differs in having a distally enlarged apical tube, its distal end with two or three distally directed teeth, and cylindrical or spindle-shaped and closed lateral spines. In fact we do not know if it has completely closed grooves or massive spines.

Etymology: From the Latin denticulatus, $-a$, -um-with teeth.

Range and occurrence: Early Late Carnian, Spongotortilispinus moixi Zone, Zulla Formation, Wadi Bani Khalid, and Haliw Formation, Hamadiyin, Oman.
Coronatubopyle omanensis Dumitrica \& Tekin n. sp. (Fig. 11j-1)

Description: Test very small, triangular or ovoid with an imperforate or poorly perforate apical tube. Apical tube cylindrical, usually with three short teeth. Test wall roughsurfaced with irregular pores. Lateral spines longovate. They represent prolongation of one primary and one secondary spine of the initial spicule.

Material: More than 30 specimens.

Holotype: Fig. 11j, Musée de Géologie Lausanne, No. 74413.

Dimensions (in $\mu \mathrm{m}$, based on three specimens): Height of test without apical tube 87-116 (holotype 87), breadth of test without lateral spines 78-100 (holotype 78), length of lateral spines $68-87$ (holotype 87 ), length of apical tube 87-89 (holotype 87), diameter of lateral spines 20-29 (holotype 29), diameter of apical tube at base 20-29 (holotype 29).

Remarks: Phylogenetically, Coronatubopyle omanensis n. sp. seems to be a perfect intermediary species between C. spelae n. sp. and C. denticulata n. sp.

Etymology: From its occurrence in Oman.

Range and occurrence: Early Late Carnian, Spongotortilispinus moixi Zone, Zulla Formation, Wadi Bani Khalid, Oman.

Coronatubopyle spelae Dumitrica \& Tekin n. sp. (Figs. 4, 11m-p)

Description: Test small, rounded triangular in face view, with two three-bladed spines corresponding to lateral spines and an apical tube. Test wall rough-surfaced, double-layered with very small, irregular, rounded, or polygonal pores on surface and wide rounded meshes on inner side. Arches of test practically invisible on surface. Apical tube smooth, cylindrical or slightly narrowing distally, without spines on border but with some pores along the zones corresponding to initial grooves of the apical spine. Lateral spines partly cylindrical because of covering of the grooves, rounded distally, and three-bladed. Cylindrical portion of lateral spines variable in length. Lateral spines aligned with left primary lateral bar and right secondary lateral bar of the initial spicule, respectively.

Material: Tens of specimens.

Holotype: Fig. 11m, Musée de Géologie Lausanne, No. 74414.

Dimensions (in $\mu \mathrm{m}$, based on eight specimens): Height of test without apical tube 77-106 (holotype 106), breadth of test without lateral spines 62-92 (holotype 92), length of lateral spines: 38-67 (holotype 56), length of apical tube 44-64 (holotype 64), diameter of lateral spines 20-28 
(holotype 28), diameter of apical tube at base 20-27 (holotype 21).

Remarks: This species differs from Coronatubopyle coronata Kozur \& Mostler and C. robusta Kozur \& Mostler in having no crown of spinules on the distal end of the apical tube and in being smaller. However, on very few specimens the beginning of a three-lobed crown may sometimes be visible. Its lateral spines resemble those of $C$. coronata and differ from those of $C$. robusta in having simple blades.

Etymology: The species is named after Dr Spela Gorican, Ljubljana, Slovenia, to honour her contributions to the knowledge of Triassic radiolarians.

Range and occurrence: Middle Carnian, Tetraporobrachia haeckeli Zone, Köseyahya section, Elbistan, SE Turkey; early Late Carnian, lower part of Spongotortilis moixi Zone, BR918, Zulla Formation, Wadi Bani Khalid, Oman.

Genus Divatella Kozur \& Mostler 1981, revised herein

Type species: Divatella spinosa Kozur \& Mostler 1981: 76.

Emended diagnosis: Test triangular-globular, singlelayered with all three spines tubular, but whereas the apical tube is completely hollow the other two tubes have in their axes or on the inner side of wall the primary lateral spines of the initial skeleton. Initial skeleton made of MB, A, V, 2Ll, 2 1, a very short D, and arches Al, VL, Ll, and AV. All arches included in the test wall, and arch AV oblique relative to the transversal plane of symmetry, very slightly marked, and partly incomplete in its apical part. Spine A included in and prolonged along the wall of apical tube. Spines L, which extend along tubular rays, originated in the middle or arches $\mathrm{Ll}$.

Remarks: Considered initially a capnuchosphaerid, because of the presence of the three tubular spines (Kozur \& Mostler 1981), translated later to the Eptingiidae (De Wever et al. 2001), this genus represents the result of very interesting evolution of some members of this family. Initial structure, illustrated for the first time in this paper, test morphology, and range suggest that it developed from Pylostephanidium Dumitrica through the intermediary of some late Longobardian species recently described by Kozur \& Mostler (2006). However, a true intermediary between one of these species and Divatella has not yet been recorded. It should have existed in the early Carnian (early Julian), but no rich and very well preserved fauna of this age, similar to that of late Longobardian and late Julian (middle Carnian) has yet been reported.

Range and occurrence: Middle Carnian, Tetraporobrachia haeckeli Zone to early Norian: Austria, Turkey, Oman, and Alaska, so far as known.
Divatella austriaca Kozur \& Mostler 1981 (Figs. 5, 11q-u)

1981 Divatella austriaca Kozur \& Mostler: 76, pl. 63 Fig. 1.

1999 Divatella austriaca Kozur \& Mostler. Tekin: 82, pl. 7 Fig. 3.

1981 Divatella spinosa Kozur \& Mostler: 76, pl. 65 Fig. 1.

1984 Divatella spinosa Kozur \& Mostler. Lahm: 85, pl. 15 Figs. 4-5.

Description: Test globular, rounded triangular in face view with small circular or oval pores and rough surface because of the development of thick bars forming conical elevations. Tubes generally poreless except for distal ends, where pores can develop, and which are expanded and bear a crown of short spines or nodes; one or two longer, radially directed spines may also exist on some specimens. Apical tube open distally, lateral tubes aligned with primary lateral spines usually closed by a porous plate. The axial beams of these spines arise from the middle of the arches Ll.

Material: Several tens of specimens.

Remarks: Maybe we are wrong, but the two species described by Kozur and Mostler (D. austriaca Kozur \& Mostler and D. spinosa Kozur \& Mostler) are herein considered synonyms because, in our opinion, the presence or absence of some small distal spines does not represent a specific character.

Range and occurrence: Middle Carnian, Tetraporobrachia haeckeli Zone: Göstling and Grossreifling, Austria; Bozkir, Konya, and Köseyahya section, Elbistan, Turkey.

Divatella robinsoni Dumitrica \& Tekin n. sp.

(Fig. 12a-e)

Description: Test circular to slightly rounded, triangular in face view, double-layered. Surface nodular, nodes interconnected by bars forming a network of usually quadrangular meshes limiting depressions with 1-4 pores. Initial spicule of thin elements. Apical and ventral bars free inside shell cavity in the portion between $\mathrm{MB}$ and arches $\mathrm{Al}$ and VL. These two arches and also arches Ll included in the wall of shell forming costae on its inner side, but not marked on the shell surface. Apical tube circular in cross section and visibly thicker than lateral tubular spines. The latter originate in the arches $\mathrm{Ll}$ and have a longitudinal furrow corresponding to the lateral spines that run along the wall of the tubes and not in their centre, forming inside a longitudinal rib. Both apical and lateral spines may have a few pores at their distal ends, which bear a crown of pores and a spine representing prolongation of apical and 

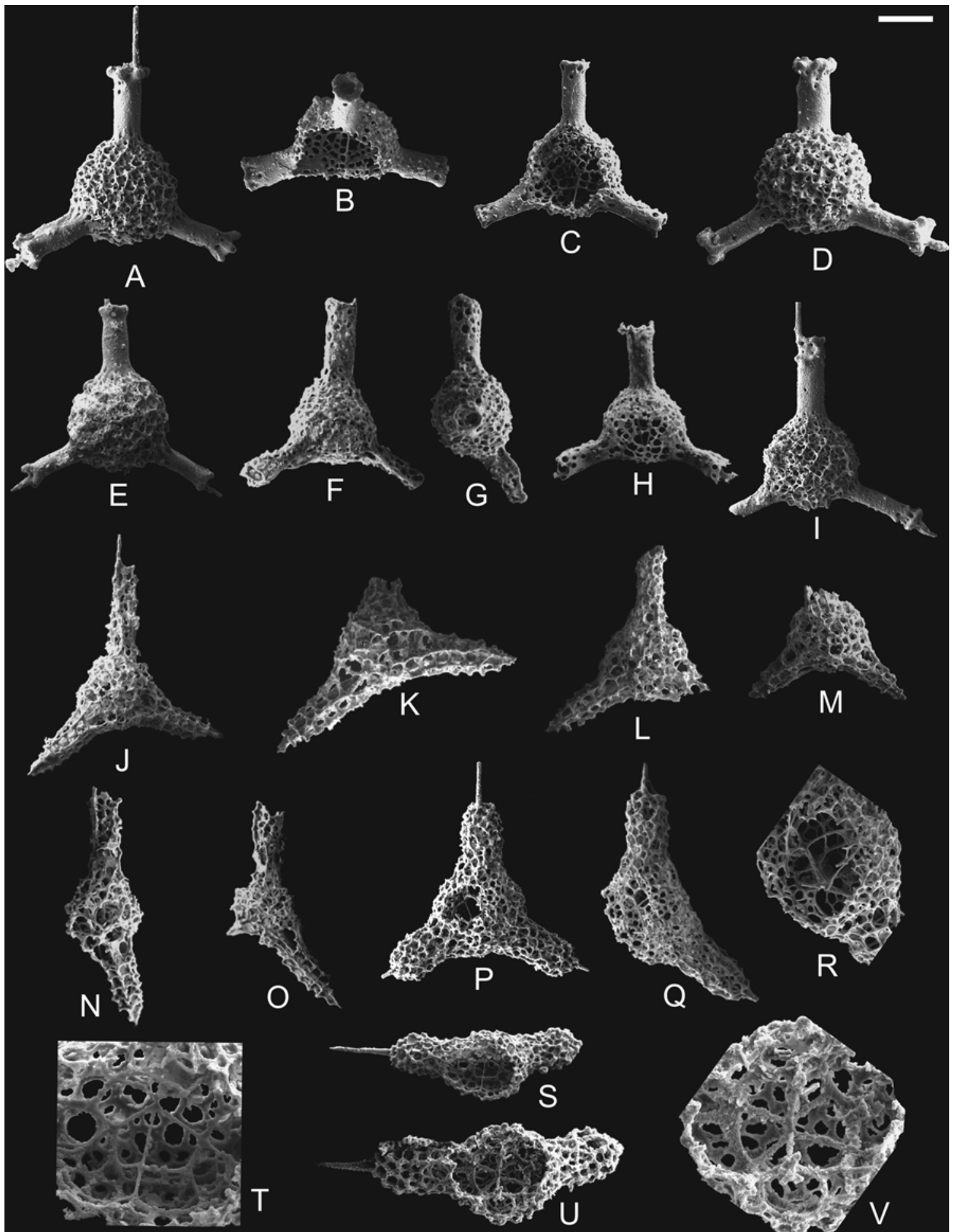

Fig. 12 a-e: Divatella robinsoni Dumitrica \& Tekin n. sp.; a holotype, GLSH; b-e paratypes; b, c same specimen in subapical and lateral views showing the initial spicule and some arches; all specimens are from GLSH; scale bar for all specimens $=80 \mu \mathrm{m}$. fh: Divatella sp. 1, 04-ELB-1; f, $\mathbf{g}$ same specimen in face and lateral views; scale bar for all specimens $=70 \mu \mathrm{m}$. i Divatella sp. 2, GLSH, scale bar $=100 \mu \mathrm{m}$. j-o: Pylostephanidium mimeticum Dumitrica \& Tekin n. sp.; j holotype, 04-ELB-1; k-o paratypes; n, o. same specimen in lateral and face views; all specimens are from 04-ELB-1; scale bar for all specimens $=80 \mu \mathrm{m}$. $\mathbf{p}-\mathbf{v}$ Veleptingium odoghertyi Dumitrica \& Tekin n. sp.; p holotype, 04-ELB-2, scale bar $=100 \mu \mathrm{m} ; \mathbf{q}-\mathbf{v}$. paratypes; q, r 04-ELB-1; $\mathbf{r}$ lateral view, detail of the initial spicule of $\mathbf{q} ; \mathbf{s}-\mathbf{v}$ specimens with apical part broken off, apical views showing the initial spicule, 04-ELB-2; $\mathbf{t}$ detail of $\mathbf{s} ; \mathbf{v}$ detail of $\mathbf{u}$; scale bar $=100,70,100,40,100$ and $40 \mu \mathrm{m}$, respectively 
lateral spines, respectively. In many cases these spines are broken off.

Material: nine specimens, of which four from the Glenn Shale, Alaska, and five from the Zulla Formation, Oman.

Holotype: Fig. 12a, Musée de Géologie Lausanne, No. 74415.

Dimensions (in $\mu \mathrm{m}$, based on four specimens): Diameter of central shell 132-171 (holotype 153), length of tubular spines (excl. needle-like distal spines) 108-115 (holotype 115), diameter of apical tube 36-46 (holotype 38), diameter of lateral tubes 31-38 (holotype 38).

Remarks: Divatella robinsoni n. sp. resembles rather well $D$. austriaca Kozur \& Mostler from which it differs in having nodular surface, a crown of distal nodes rather than distal spines, and essentially in that the lateral spines do not run along the centre of lateral tubes but on one side of the wall of tubes.

Etymology: The species is named after Dr Bradford Eugene Robinson, USA, who provided the radiolarian sample of the Glenn Shale containing the best-preserved specimens of this species.

Range and occurrence: Late Carnian to early Norian, Glenn Shale, Alaska and Zulla Formation, Wadi Bani Khalid (BR923), Oman.

\section{Divatella sp. 1 (Fig. 12f-h)}

Remarks: By its morphology, this taxon, from which we only have the illustrated specimen, seems to be a primitive member of the genus, parts of its lateral spines resembling somehow the lateral spines of the late Ladinian species Carterella magniporata Kozur \& Mostler.

Range and occurrence: Middle Carnian, Tetraporobrachia haeckeli Zone, Köseyahya section, Elbistan, SE Turkey.

\section{Divatella sp. 2 (Fig. 12i)}

Remarks: This taxon differs from D. robinsoni $\mathrm{n}$. sp., only in having no crown of nodes at the distal part of the apical tube but nodes on the distal, perforated quarter and also narrow lateral tubes bearing a perforated neck below the crown of nodes on the only completely preserved tube. Because we have a single specimen we do not know if these peculiarities characterize a new species or if the specimen represents a variety of the species Divatella robinsoni n. sp.

Range and occurrence: Late Carnian or earliest Norian, Glenn Shale, Alaska.

Genus Pylostephanidium Dumitrica 1978, revised herein

1978 Pylostephanidium Dumitrica: 34, type species Pylostephanidium clavator Dumitrica 1978.
1991 Spicularina Donofrio: 207, type species Spicularina ericae Donofrio, 1991.

2006 Carterella Kozur \& Mostler: 49, type species Carterella longispinosa Kozur \& Mostler, 2006.

2006 Praedivatella Kozur \& Mostler: 51, type species Praedivatella rugosa Kozur \& Mostler, 2006.

Revised diagnosis: Eptingiidae with an open, perforated apical tube, in the wall of which is included the apical spine, and with two three-bladed lateral spines with nodes on blades. Central part of shell globular. Spicule inside test cavity with open sagittal ring and oblique to the plane of bilateral symmetry. Lateral spines aligned with one primary lateral bar of the spicule and one diagonally opposite secondary lateral bar or originating in the arches Ll.

Remarks: Finding of Pylostephanidium mimeticum n. sp. and of other eptingiids with apical tube proves that the distinctive character of the genus should be: a globose central shell, perforated apical tube with the apical bar of the initial spicule included in its wall and expressed or not into a spine, lateral spines provided with nodes and nodes interconnected by bars. With the type species, which is the oldest, these connections are very weak, but they became denser with younger species.

The genus Spicularina Donofrio, represented by only its type species and very badly preserved, is a slightly more evolved species of Pylostephanidium. Kozur \& Mostler (2006) considered it as a Late Triassic genus, but the morphology of its lateral spines seems to be less evolved than that of the spines of Praedivatella.

The genus Carterella Kozur \& Mostler, with C. longispinosa Kozur \& Mostler 2006 as type species, is a junior synonym of Pylostephanidium Dumitrica. Under this genus Kozur \& Mostler (2006) described five species; two of them $(C$. transita Kozur \& Mostler and the type speciesC. longispinosa Kozur \& Mostler) should be assigned to the genus Pylostephanidium, the other three species $(C$. brevispinosa Kozur \& Mostler, C. magniporata Kozur \& Mostler, and C. subrotunda Kozur \& Mostler) are closer to the new genus Veleptingium and should be assigned to it. The first two species differ from the type species of $P y$ lostephanidium only in having more bars connecting the nodes of the lateral spines, whereas the perforated and open apical tube, with the apical spine included in the wall of the tube, is similar. They are nothing other than more evolved species of this genus, which seems to have a trend toward closing the grooves of the lateral spines, a trend which is already becoming apparent in the latest Anisian-early Ladinian P. clavator Dumitrica. As we discuss below, a similar trend took place with the genus Coronatubopyle.

Similarly, the genus Praedivatella Kozur \& Mostler comprises a few more evolved species of Pylostephanidium. The globular cortical shell is similar in both genera, their lateral spines are always nodose and the grooves are 
more or less covered externally on the proximal part. Also, the apical tube is similar having the apical spine prolonged on one side of the wall. As remarked under Carterella, the cover of the grooves is becoming apparent in the genus Pylostephanidium. So the differences between these two genera are not of structure but of grade. That is why in this paper, we prefer to consider Praedivatella Kozur \& Mostler as a junior synonym of Pylostephanidium Dumitrica. If we want to use it, we should consider it a subgenus of Pylostephanidium. Otherwise our genera are reduced to the type species or to very few species. Anyway, in agreement with Kozur \& Mostler (2006), Praedivatella is an intermediary stage between Pylostephanidium and Divatella. The series Pylostephanidium-Praedivatella as an evolved stage of Pylostephanidium-Divatella is one of the very interesting and undoubted phylogenetic lineages in the evolution of the Triassic Eptingiidae. Although some connecting species are probably missing, along this lineage one can see very well that the appearance of the tubular lateral spines of Divatella was a gradual evolutionary process. The same thing cannot be said about the appearance of the apical tube with Pylostephanidium, for which there is not yet a fossil record of a gradual transition from a simple spine to the tube.

The genus Coronatubopyle Kozur \& Mostler is also close to Pylostephanidium Dumitrica but differs from it in having a triangular test, lateral spines without nodes, and cortical test with polygonal pores. According to Kozur \& Mostler (2006), it appeared probably from Triassistephanidium Dumitrica. It is possible that they are right but we think that it is much easier to consider it as originating from Pylostephanidium, which already has an apical tube, by the loss of nodes. This possibility is also supported by its initial skeleton, which is of Pylostephanidium type and not of Triassistephanidium type.

Range: Latest Anisian (late Illyrian) or early Ladinian to Middle Carnian so far as is known.

\section{Pylostephanidium mimeticum Dumitrica \& Tekin n. sp.} (Fig. 12j-o)

Description: Central shell small, globose and asymmetric, thin-walled with irregular surface, and rather wide, rounded polygonal, usually quadrangular or pentagonal pores of very variable sizes. Intervening bars usually rectangular in transverse section with sharp edges. Plane of sagittal ring oblique, the arch $\mathrm{AV}$ connecting the apical spine inside the test at about $2 / 3$ to $3 / 4$ from the base of the shell. Apical bar free within shell cavity then inserted in the wall of the apical tube and prolonged beyond its end into a small spine. Arches Al and VL in the close vicinity of the shell wall with which they are connected in several places. The two lateral spines three-bladed bearing up to 7-8 verticils of three nodes, which are forked in the transverse plane to the spine forming six secondary nodes. Nodes decreasing distally in size and interconnected longitudinally and transversally by bars, resulting in six longitudinal cortical beams, maximum 4-5 circumferential bars and crests, and six longitudinal rows of wide square pores in square pattern. Pores of apical tube also large but irregular or ovate.

Material: seven specimens in sample 04-Elb-1.

Holotype: Fig. 12j, Musée de Géologie Lausanne, No. 74416.

Dimensions (in $\mu \mathrm{m}$, based on five specimens): Diameter of central shell 93-120 (holotype 120), length of spines 93145 (holotype 141), breadth of spines at base 32-54 (holotype 32).

Remarks: What is interesting about this species is the perfect resemblance between the morphology of its lateral spines and the morphology of the spines of the co-occurring species Tetraporobrachia haeckeli Kozur \& Mostler. We wonder if this amazing resemblance could not be the result of a horizontal gene transfer, a hypothesis advanced for similar cases by Dumitrica \& Guex (2003). A morphologically closely related species is also the late Ladinian species Pylostephanidium transitum (Kozur \& Mostler) $=$ Carterella transita Kozur \& Mostler, which has somewhat similar lateral spines, whereas with $P$. longispinosum (Kozur \& Mostler) $=$ C. longispinosa Kozur \& Mostler the pores of the lateral spines are less regularly arranged. These species could also suggest a gradual transition from the more or less perfect arrangement of the bars along these spines to the perfect arrangement characteristic of this species.

Etymology: From the late Latin mimeticus-exhibiting mimicry, because its lateral spines resemble the spines of the genus Tetraporobrachia.

Range and occurrence: Middle Carnian, Tetraporobrachia haeckeli Zone, Köseyahya section, Elbistan, SE Turkey.

Genus Veleptingium Dumitrica \& Tekin n. gen.

2006 Carterella Kozur \& Mostler, part.: 49.

Type species: Veleptingium odoghertyi n. sp.

Diagnosis: Three-armed, large eptingiids without pylome or with a narrow one, with the initial spicule and arches included inside a velum-like cortical shell. Arms built along apical and primary lateral spines.

Remarks: This genus differs from all the other genera of the family Eptingiidae by having the whole skeleton, arms included, covered by a cortical shell. By this character, it resembles the species Eptingium aljilense n. sp., from which it differs in having no aperture between spines A and one L, but a small one at the end of the apical arm, 
and very small needle-shaped spines at the distal end of arms. Given this resemblance and the ancientness of the cited species, it is possible that Veleptingium n. gen. originated in E. aljilense n. sp. by the disappearance of the aperture and reduction of the distal spines. The three species described by Kozur \& Mostler (2006) under the genus Carterella (C. subrotunda, C. magniporata, and C. brevispinosa) could be also assigned to this genus.

The place of Veleptingium n. gen. within the Divatellinae is questionable. Some species or specimens have a pylome partly similar to that of Pylostephanidium Dumitrica, whereas others (see the holotype of $V$. odoghertyi $n$. sp.) have no such a structure.

Etymology: An Eptingium with a velum-like cortical shell.

Range: Late Ladinian (middle-late Longobardian), Muelleritortis cochleata Zone, Spongoserrula fluegeli Subzone, to middle Carnian, Tetraporobrachia haeckeli Zone.

Veleptingium odoghertyi Dumitrica \& Tekin n. sp. (Figs. 12p-v, 13a, b)

Description: Initial spicule as with the genus, thin. Cortical shell thin-walled with polygonal, irregular pores in size and arrangement. Central part of cortical shell slightly globular. Arms thick, cylindrical, about as long as ray of central shell, with rounded ends and a needle-like spine representing continuation of the spine $\mathrm{A}$ and $\mathrm{L}$ of the initial spicule.

Material: ten specimens.

Holotype: Fig. 12p, Musée de Géologie Lausanne, No. 74417.

Dimensions (in $\mu \mathrm{m}$, based on eight specimens): Diameter of central shell 117-194 (holotype 162), length of arms 113-161 (holotype 125), diameter of arms 67-96 (holotype 74).

Remarks: Veleptingium odoghertyi n. sp. is morphologically very close to Carterella subrotunda Kozur \& Mostler 2006 and C. brevispinosa Kozur \& Mostler 2006 from which it differs in having a more inflated central shell and thicker arms with rounded tips.

Etymology: The species is named after $\operatorname{Dr}$ Luis O'Dogherty, Spain, to honour his contributions to the knowledge of Mesozoic radiolarians.

Range and occurrence: Middle Carnian, Tetraporobrachia haeckeli Zone, Köseyahya section, Elbistan, SE Turkey.

Genus Triassolaguncula Dumitrica \& Tekin n. gen.

Type species: Triassolaguncula tetrapes $\mathrm{n}$. $\mathrm{sp}$.

Diagnosis: Test very small, amphora-shaped with an apical tube and four spines at base of test aligned with primary and secondary lateral bars of the initial spicule. Spicule consisting of a median bar, apical, ventral, and dorsal bars, two pairs of lateral bars that can be differentiated into primary and secondary, or not, and arches between them, of which one is more or less circular, and connect in the transversal plane the ends of apical and ventral spines. Apical and ventral bars terminated approximately in the middle of shell, never extended outside, whereas both pairs of lateral bars projected outside into spines. Spines three-bladed. Shell without sagittal ring.

Remarks: This new genus, currently represented by its type species only, resembles structurally the genus Coronatubopyle Kozur \& Mostler and especially the co-occurring species Coronatubopyle spelae $\mathrm{n}$. $\mathrm{sp}$. from which it differs especially in having all lateral bars of the initial spicule projected outside into spines.

Etymology: From its occurrence in the Triassic and the Latin laguncula-small carafe.

Range: Middle Carnian, Tetraporobrachia haeckeli Zone to early Late Carnian, Spongotortilispinus moixi Zone.

Triassolaguncula tetrapes Dumitrica \& Tekin n. sp. (Fig. 13c-h)

Description: Spicular system as with the genus. Test very small, bottle-shaped or ovoid with an imperforate or poorly perforate tube at the apical part. Test wall with irregular pores, rough-surfaced, having a tendency to become spongy. Basal part flat with four-bladed, laterally directed pyramidal spines.

Material: More than 30 specimens.

Holotype: Fig. 13c, d, Musée de Géologie Lausanne, No. 74418.

Dimensions (in $\mu \mathrm{m}$, based on six specimens): Height of shell 125-156 (holotype 125), diameter of shell without spines 67-84 (holotype 67).

Remarks: There is no connection between the apical spine and the tube because both apical and ventral spines are not differentiated and terminate in the shell before the base of the tube.

Etymology: From the Greek tetra-four and pes-foot.

Range and occurrence: Middle Carnian, Tetraporobrachia haeckeli Zone, Köseyahya section, Elbistan, SE Turkey; early Late Carnian, Spongotortilispinus moixi Zone, Zulla Formation, Wadi Bani Khalid, Oman.

Family Spongosaturnaloididae Kozur \& Mostler 1983

1983 Saturnaloididae Kozur \& Mostler: 9.

1990 Spongosaturnaloididae (nom. corr.) Kozur \& Mostler: 186.

2001 Spongosaturnaloididae Kozur \& Mostler. De Wever et al.: 188-189. 


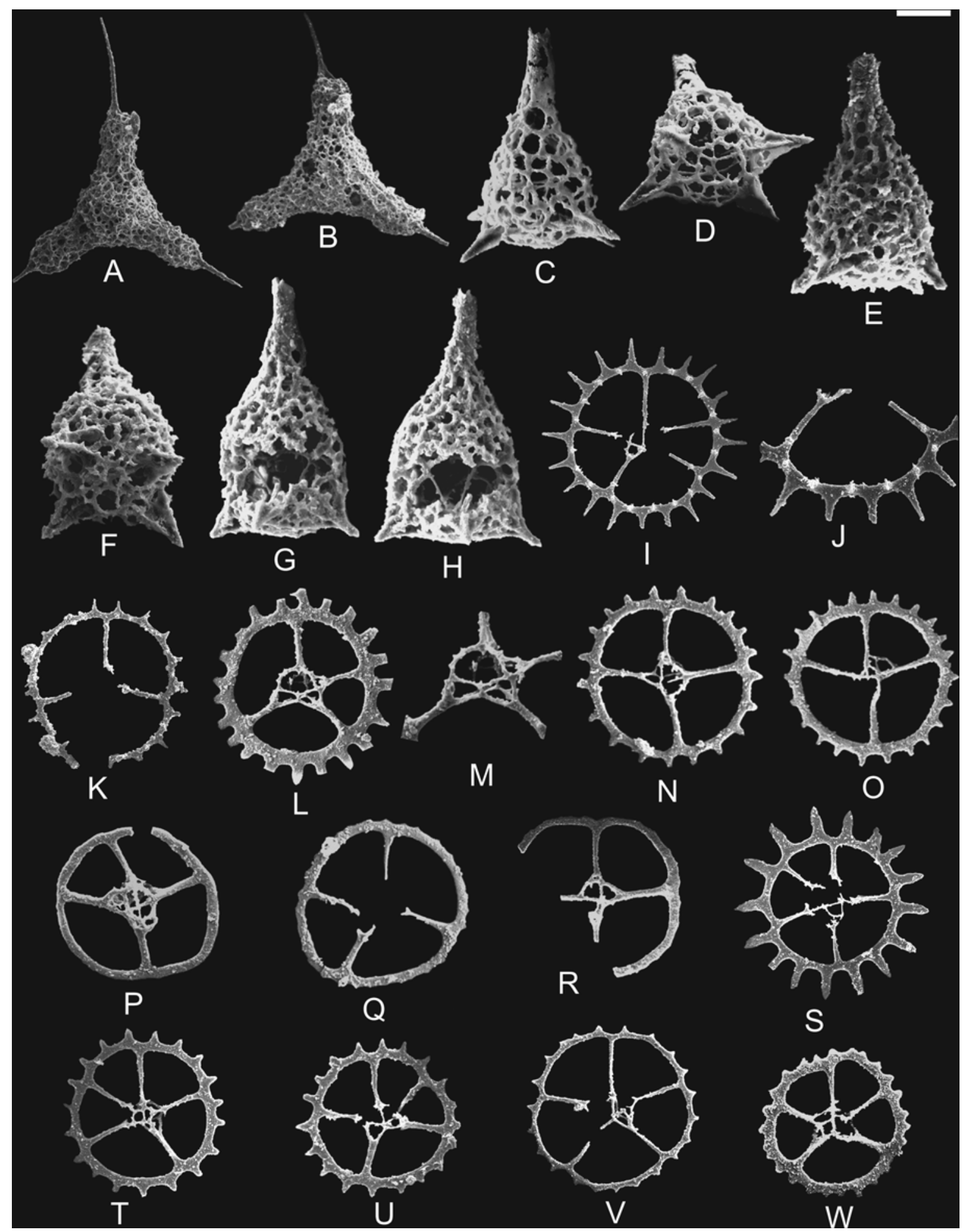

Fig. 13 a-b Veleptingium odoghertyi Dumitrica \& Tekin n. sp., paratypes; a 04-ELB-2; b 04-ELB-3; scale bar for both figures $=100 \mu \mathrm{m}$. $\mathbf{c}-\mathbf{h}$ Triassolaguncula tetrapes Dumitrica \& Tekin n. sp.; c-d holotype in lateral and basal views showing the initial spicule; $\mathbf{e}-\mathbf{h}$ paratypes; $\mathbf{f}$ same as $\mathbf{e}$, basal view; $\mathbf{g}$, $\mathbf{h}$ same specimen viewed at different angles; all specimens are from 04-ELB-1; scale bar for all specimens $=30 \mu \mathrm{m}$. $\mathbf{i}-\mathbf{k}$ Spongosaturnaloides macilentus Dumitrica \& Tekin n. sp.; i-j holotype, 04-ELB-2; $\mathbf{j}$ detail of the ring of $\mathbf{i}$; scale bar $=80$ and $40 \mu \mathrm{m}$, respectively; $\mathbf{k}$ paratype, 04-ELB-4, scale bar $=80 \mu \mathrm{m}$. l-r: Spongosaturnaloides multidentatus Kozur \& Mostler, l-m 04-ELB-1; $\mathbf{m}$ detail of the initial spicule of $\mathbf{l} ; \mathbf{n}$ 04-ELB2; o-q 04-ELB-1; r 04-ELB-5; scale bar $=80,40,70,80,60,70$ and $70 \mu \mathrm{m}$, respectively. s-w Spongosaturnaloides quinquespinosus Kozur \& Mostler; all specimens are from 04-ELB-2; scale bar $=90,70$, 70,90 and $80 \mu \mathrm{m}$, respectively 
Diagnosis: Entactinarian Eptingiacea with a peripheral ring surrounding an initial spicular system of nassellarian type consisting of a median bar (MB) with an apical bar (A), a ventral bar $(\mathrm{V})$, two primary lateral bars $\left(\mathrm{L}_{\mathrm{r}}\right.$ and $\left.\mathrm{L}_{\mathrm{l}}\right)$, two secondary lateral bars $\left(\mathrm{l}_{\mathrm{r}}\right.$ and $\left.\mathrm{l}_{\mathrm{l}}\right)$, and a very short dorsal spine (D). Except for D, all the other bars interconnected by arches: AV forming a sagittal ring, $2 \mathrm{LV}$, two Ll, and 2 Al. The spicular system may be interconnected by a latticed shell forming a pseudocephalis or a medullary shell. $A$ and the two L long and united distally by a peripheral ring, that can be simple, surrounded by a row of pores, or a lattice circular plate. One or two radial bars on the direction of 1 bars, but not directly connected to them, may also unite the central shell to the ring within the interval between $\mathrm{A}$ and L. A vellum-like shell may also be developed on both sides from the ring, covering the space inside it.

Remarks: Initially the family was compared with the family Austrisaturnalidae because of the presence of the ring (Kozur \& Mostler 1983). Later (De Wever et al. 2001), on the basis of the poorly illustrated spicular system known until that date, the family was reinterpreted as having a nassellarian spicule and system of arches, and as being close to the family Eptingiidae. The very well-preserved specimens found in the Elbistan material reinforce this interpretation and, moreover, allow us to know the initial skeleton in detail, and to make more precise some points still obscure or only suggested before. They show that the dorsal spine is present but very short, and that the radial bars extended on the direction of the secondary lateral spines in some species or specimens are not directly connected to them. This indirect connection probably explains why these bars may be missing in some species. These two new elements are additional arguments in favour of the structural similarity of this family to the family Eptingiidae. Regarded as such, the Spongosaturnaloididae can be regarded as Eptingiidae with a peripheral ring. It seems that it originated in a species of Cryptostephanidium Dumitrica or Spongostephanidium Dumitrica by the appearance of a ring at the distal part of the three spines characteristic of the family Eptingiidae through a horizontal gene transfer from a Carnian saturnalid species. The possibility of this transfer is also supported by the absence of transitional specimens or species between these two families. No early Carnian eptingiid with half-built ring or branched spines A and L, suggesting a gradual appearance, has yet been recorded

The family Spongosaturnaloididae comprises only two genera-Spongosaturnaloides Kozur \& Mostler and Ploechingerella Kozur \& Mostler, differentiated by the morphology of the ring: simple or armed with spines in the former genus, with pores around it in the latter. These characters are rather constant in almost all species excepting two (Ploechingerella elbistanensis n. sp. and P. irregularis n. sp.), which contain both specimens without pores and specimens with a complete or incomplete ring of pores.

As specific taxonomic characters, we take into account not only the morphology of the ring but also the number of rays between the central shell and the ring. Corroborated with the morphology of the ring, this number (3-5) seems to be rather constant at the species level. Splitting the genera according to the number of rays does not seem realistic, because the rays that would correspond to secondary lateral spines are not prolongations of these spines.

A phylogeny of the subfamily is difficult to make in the present state of knowledge of the fossil record, because of almost sudden appearance of both genera and of all species so far known. However, it would be logical to consider Spongosaturnaloides as the forerunner of Ploechingerella because of its more complex skeleton.

Range and occurrence: Middle Carnian (Tetraporobrachia haeckeli Zone) to early late Carnian (Spongotortilispinus moixi Zone) of Austria, Greece, Turkey, and Oman so far as known.

\section{Genus Spongosaturnaloides Kozur \& Mostler 1972}

1972 Spongosaturnaloides Kozur \& Mostler n. subgen.: 42.

1983 Spongosaturnaloides Kozur \& Mostler. Kozur \& Mostler: 10.

Type species: Spongosaturnalis (Spongosaturnaloides) quinquespinosa Kozur \& Mostler 1972.

Remarks: Unlike Ploechingerella Kozur \& Mostler the species of this genus never have a velum within the area of the ring, and the ring is simpler. Spongosaturnaloides seems, therefore, to be older and to make the connection between Ploechingerella Kozur \& Mostler and the eptingiid genus Cryptostephanidium Dumitrica or Spongostephanidium Dumitrica, in which Spongosaturnaloides seems to have originated.

Based on the constancy of the number of connecting rays between the medullary shell and the ring with the species of the genus Ploechingerella (see below), we consider that the same constancy may characterize the species of the genus Spongosaturnaloides. As a consequence we include in different species specimens with a similar ring but with a different number of connecting rays. Also, we include in this genus only species that show no trends to build a porous ring.

Range and occurrence: Middle Carnian, Tetraporobrachia haeckeli Zone: Austria, Turkey, and Oman.

Spongosaturnaloides macilentus Dumitrica \& Tekin n. sp. (Fig. 13i-k)

Description: Test with five or possibly four connecting rays. Ring very thin with about $17-20$ very thin spines. 
Both sides of ring with thorns directed up and down from the intervals between spines, each interval having on each side a single thorn so that their number is equal to the number of spines.

Material: three specimens.

Holotype: Fig. 13i, j, Musée de Géologie Lausanne, No. 74419.

Dimensions (in $\mu \mathrm{m}$, based on two specimens): Diameter of inner ring 184-200 (holotype 200), diameter of outer ring without teeth 207-225 (holotype 225).

Remarks: This species resembles S. quinquespinosus Kozur \& Mostler in having five connecting rays but differs from it in having the ring and spines very thin and thorns on both sides of the ring in the intervals between spines. By this last character this species is close to Ploechingerella, and especially $P$. subcerniculum $\mathrm{n}$. sp. from which it differs in having no porous plate.

Etymology: From the Latin macilentus, - $a$, -um-thin.

Range and occurrence: Middle Carnian, Tetraporobrachia haeckeli Zone, Köseyahya section, Elbistan, SE Turkey.

Spongosaturnaloides multidentatus Kozur \& Mostler 1983 (Fig. 131-r)

1983 Spongosaturnaloides multidentatus Kozur \& Mostler: 11-12, pl. 3 Fig. 1.

non 1999 Spongosaturnaloides multidentatus Kozur \& Mostler. Tekin: 127, pl. 25 Fig. 5.

Description: Initial spicule as with the genus, connected to the ring by four rays (A, two $\mathrm{L}$ and one 1 ). Ring with 18 28 small spines or teeth, most frequently 22-26; rarely the teeth are very small, very rarely the ring is toothless, smooth.

Material: More than 100 specimens.

Remarks: Most specimens from the Elbistan fauna differ from the holotype by having less robust spines and smaller teeth.

Range and occurrence: Middle Carnian, Tetraporobrachia haeckeli Zone, Göstling, Austria, and Köseyahya section, Elbistan, SE Turkey.

Spongosaturnaloides quinquespinosus Kozur \& Mostler 1972 (Fig. 13s-w)

1972 Spongosaturnalis (Spongosaturnaloides) quinquespinosa Kozur \& Mostler: 42, pl. 2 Figs. 4, 5, 9; pl. 4 Fig. 3.

1981 Spongosaturnaloides quinquespinosus Kozur \& Mostler: 54, pl. 61 Fig. 4.

1983 Spongosaturnaloides quinquespinosus Kozur \& Mostler. Kozur \& Mostler: pl. 2 Fig. 3.
Fig. 14 a-f Spongosaturnaloides triradiatus Dumitrica \& Tekin n. sp.; a holotype, 04-ELB-2, scale bar $=70 \mu \mathrm{m}$; b-f paratypes; b-d 04-ELB-2; d detail of the initial spicule of c; e, f 04-ELB-5; scale bar $=70,70,25,70$ and $70 \mu \mathrm{m}$, respectively. g-m, o, q: Ploechingerella (?) elbistanensis Dumitrica \& Tekin n. sp.; g holotype, 04ELB-2, scale bar $=90 \mu \mathrm{m} ; \mathbf{h}-\mathbf{m}, \mathbf{o}, \mathbf{q}$ paratypes; $\mathbf{h}-\mathbf{j}$. 04-ELB-2; $\mathbf{i}$ detail of the initial spicule of $\mathbf{h} ; \mathbf{j}$ oblique view; $\mathbf{k}-\mathbf{m}, \mathbf{o}$ 04-ELB-1; $\mathbf{l}$ detail of the initial spicule of $\mathbf{k} ; \mathbf{q}$ 04-ELB-1; scale bar = 90, 40, 90, 90, 40, 90, 90, 90, 80 and $90 \mu \mathrm{m}$, respectively. n, p, r-t Ploechingerella irregularis Dumitrica \& Tekin $\mathrm{n}$. sp.; $\mathbf{r}$ holotype, 04-ELB-5, scale bar $=110 \mu \mathrm{m} ; \mathbf{n}, \mathbf{p}, \quad \mathbf{s}, \quad \mathrm{t}$ paratypes, 04-ELB-5, scale bar $=100 \mu \mathrm{m}$. u-v Ploechingerella subcerniculum Dumitrica \& Tekin n. sp., holotype, 04-ELB-2; $\mathbf{v}$ detail of the initial spicule of $\mathbf{u}$; scale bar $=120$ and $30 \mu \mathrm{m}$, respectively

1984 Kozurastrum ? quinquespinosum (Kozur \& Mostler). Lahm: 105, pl. 19 Fig. 2.

1990 Spongosaturnalis multidentatus Kozur \& Mostler. Budai \& Dosztaly: pl. 2 Fig. 2.

Material: ten specimens in samples 04-ELB-1, 04-ELB2 and 04-ELB-4.

Remarks: The specimens occurring in the Elbistan samples are generally less robust than those from Austria and West Carpathians. Also, they have usually more spines, and the spines are of various lengths. Specimens resembling the topotype specimens are rare.

Range and occurrence: Middle Carnian, Tetraporobrachia haeckeli Zone: Göstling and Grossreifling, Austria; West Carpathians; Köseyahya section, Elbistan, SE Turkey and Zulla Formation, Wadi Bani Khalid section, Oman.

Spongosaturnaloides triradiatus Dumitrica \& Tekin n. sp. (Fig. 14a-f)

Description: Initial spicule as with the genus, connected to the ring by 3 radial bars aligned with $A, L_{r}$, and $l_{1}$. Ring circular or trilobate with 22-29 very short teeth or practically without teeth.

Material: 15 specimens in samples 04-ELB-1 and 04ELB-2.

Holotype: Fig. 14a, Musée de Géologie Lausanne, No. 74420 .

Dimensions (in $\mu \mathrm{m}$, based on five specimens): Inner diameter of ring 163-207 (holotype 163), outer diameter of ring without teeth 197-233 (holotype 233).

Remarks: Spongosaturnaloides triradiatus n. sp. resembles S. multidentatus Kozur \& Mostler and S. quinquespinosus Kozur \& Mostler from which it differs in having only three rays between the initial skeleton and the ring.

Etymology: From the Latin tri-three and radiatuswith rays.

Range and occurrence: Middle Carnian, Tetraporobrachia haeckeli Zone, Köseyahya section, Elbistan, SE Turkey. 

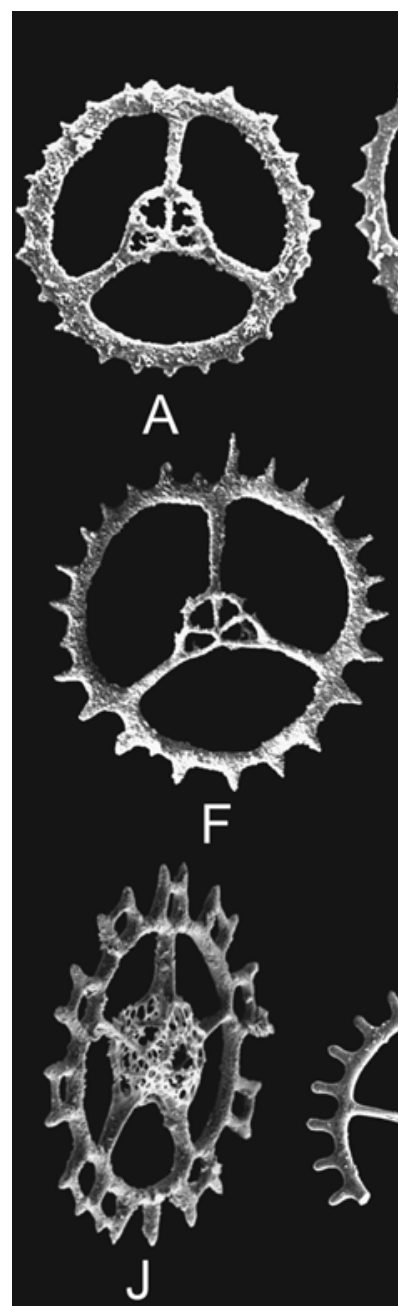

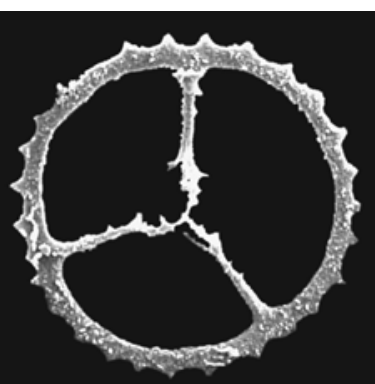

B

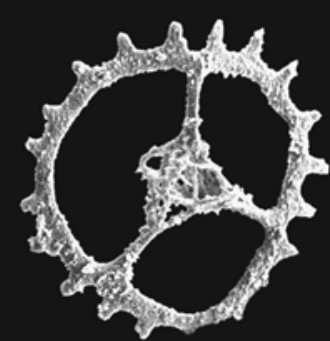

C

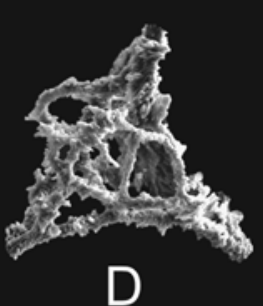

D

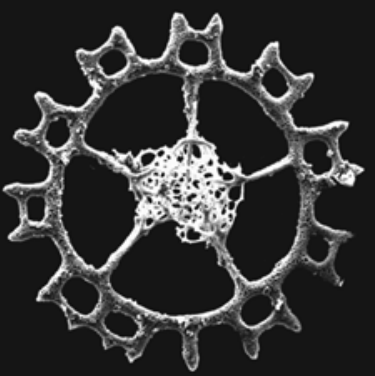

$\mathrm{H}$
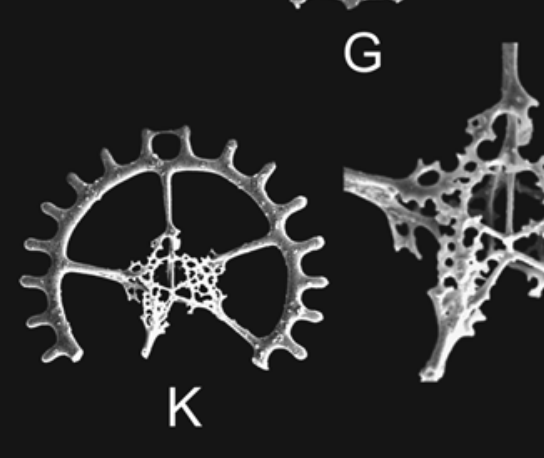

G

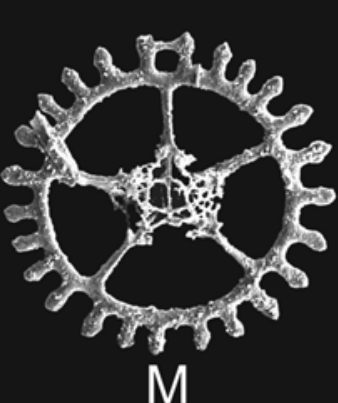

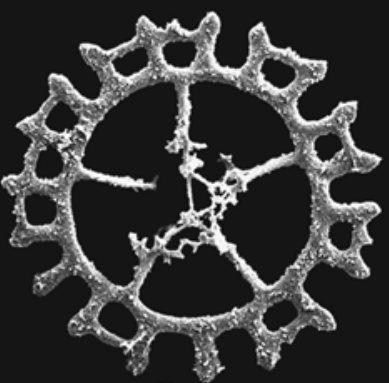

O

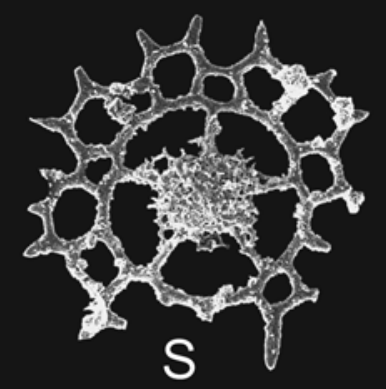

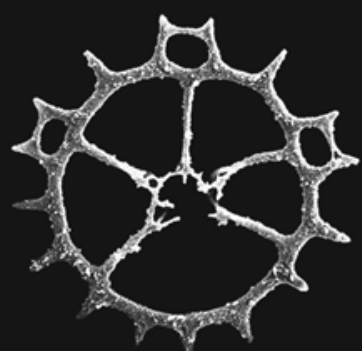

$\mathrm{P}$

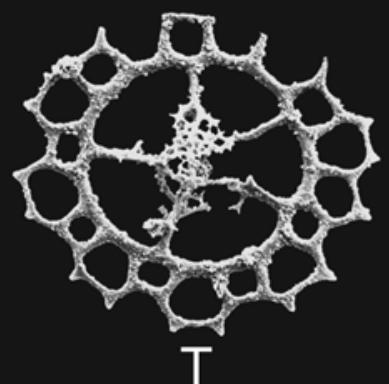

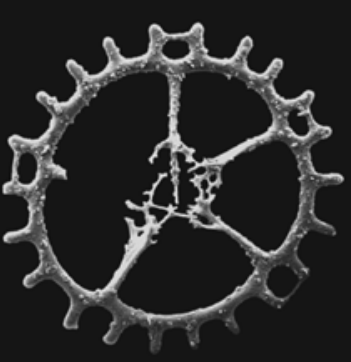

Q

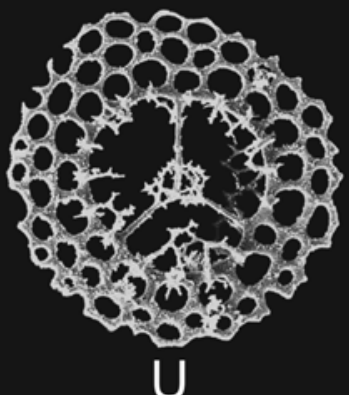

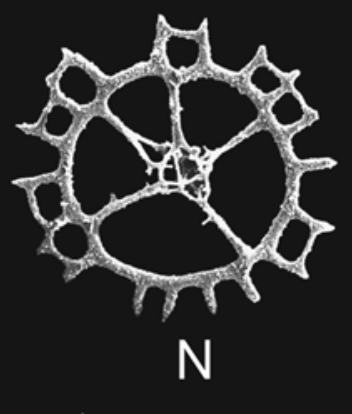

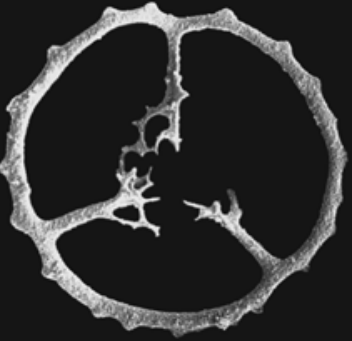

E

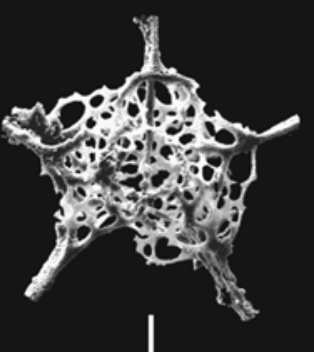

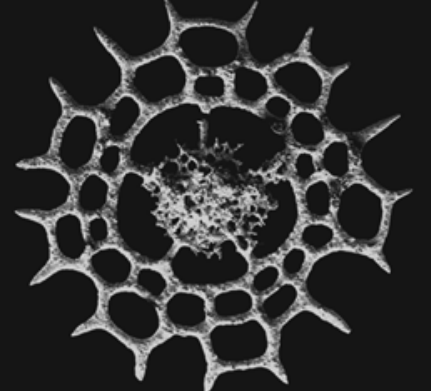

R

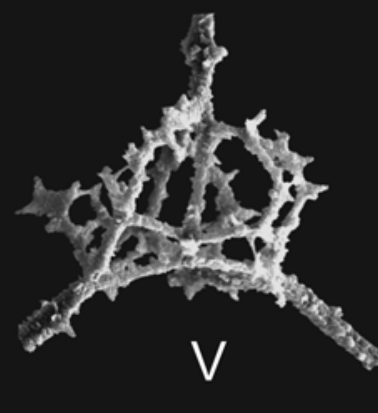


Genus Ploechingerella Kozur \& Mostler 1983 revised

1983 Ploechingerella n. gen. Kozur \& Mostler: 9.

Type species: Parasaturnalis (Japonisaturnalis) multiperforatus Kozur \& Mostler 1972: 44.

Revised diagnosis: Spicular system as with family. Medullary test discoidal, connected to the ring by 3-5 rays representing prolongations of bars $A, L_{r}$, and $L_{l}$, or A, $\mathrm{L}_{\mathrm{r}}, \mathrm{L}_{\mathrm{l}}, \mathrm{l}_{\mathrm{r}}$, and $\mathrm{l}_{1}$. Ring consisting of 1-3 circular rows of pores. Test with or without a discoidal velum inside the ring.

Remarks: The correlation between the morphology of the test and the number of rays suggests that the number of rays connecting the medullary shell to the ring is constant for each species. Unlike the genus Spongosaturnaloides no species of the genus Ploechingerella with four connector rays between the medullary shell and ring has yet been recorded.

Range and occurrence: Middle Carnian, Tetraporobrachia haeckeli Zone of Austria and Turkey; early Late Carnian, Spongotortilispinus moixi Zone of Oman.

Ploechingerella elbistanensis Dumitrica \& Tekin n. sp.

(Fig. 14g-m, o, q)

1972 Spongosaturnalis (Spongosaturnaloides) quinquespinosus Kozur \& Mostler: 42, pl. 2 Fig. 5, non pl. 2 Figs. 4, 9.

1999 Spongosaturnaloides multidentatus Kozur \& Mostler. Tekin: 127, pl. 25 Fig. 5.

Description: Initial skeleton as for the genus. Medullary shell pentagonal in ventral or dorsal views connected to first ring by five rays representing prolongation of bars A, $\mathrm{L}_{\mathrm{r}}, \mathrm{L}_{\mathrm{l}}, \mathrm{l}_{\mathrm{r}}$, and $\mathrm{l}_{1}$. Ring simple with 16-26, usually 20-24, short, blunt spines, which can be distally interconnected by tangential bars forming a row of trapezoidal pores. This row is rarely complete, most frequently only part of spines is interconnected in such a manner. Radial bars separating the pores prolonged outside the second ring into short teeth. Test without velum inside the ring.

Material: seven specimens in sample 04-ELB-1, 13 in sample 04-ELB-2, two in sample 04-ELB-4, not all illustrated.

Holotype: Fig. 14g, Musée de Géologie Lausanne, No. 74421.

Dimensions (in $\mu \mathrm{m}$, based on 12 specimens): Diameter of inner ring 167-229 (holotype 222), diameter of outer ring without teeth 225-328 (holotype 311).

Remarks: Morphologically this species is intermediary between Spongosaturnaloides and Ploechingerella. The juvenile specimens, without pores, could be assigned to the former genus, whereas the mature specimens, with complete or partly complete outer ring could be assigned to the latter genus. Assignation of the two extreme morphotypes to two different species or genera is impossible because of the large number of intermediary forms. A similar situation occurs with Spongosaturnaloides quinquespinosus Kozur \& Mostler from which this new species differs only in having a greater number of spines, the number of spines of the former species varying between 13 and 16 according to the figures so far published (Kozur and Mostler 1972, 1983; Lahm 1984) and to the original and subsequent descriptions. The spines of $S$. quinquespinosus seem also to be commonly pointed whereas those of this new species are robust and blunt. Ploechingerella elbistanensis $\mathrm{n}$. $\mathrm{sp}$. is rather similar to $P$. torquis $\mathrm{n}$. $\mathrm{sp}$. in having a single row of pores, but differs from this species in the position and number of peripheral spines relative to the bars separating the pores, and in having five rather than three rays between the medullary shell and the ring. The specimens without pores of $P$. elbistanensis are also almost perfectly similar to the holotype of Spongosaturnaloides multidentatus Kozur \& Mostler, from which they differ in having five instead of four rays between the medullary shell and the ring.

Etymology: From Elbistan, type locality of the species.

Range and occurrence: Middle Carnian, Tetraporobrachia haeckeli Zone, Bozkir, Konya, and Köseyahya section, Elbistan, Turkey; early Late Carnian, lower part of Spongotortilispinus moixi Zone, Wadi Bani Khalid, Oman.

Ploechingerella irregularis Dumitrica \& Tekin n. sp. (Fig. 14n, p, r-t)

1979 Parasaturnalis (?) sp. cf. P. (Japonosaturnalis) japonicus (Yao). De Wever et al.: 80, pl. 1 Fig. 13.

1982 Japonosaturnalis ? sp. aff. J. japonicus (Yao). De Wever: 211, pl. 13 Figs. 7, 8.

1993 Parasaturnalis sp. Sashida et al.: 89, Fig. 6-19.

Description: Medullary shell pentagonal with initial skeleton as with the genus, connected to the ring by five rays representing prolongation of $\mathrm{A}, \mathrm{L}$, and 1 . First ring of pores with 16-18 quadrangular to hexagonal pores of variable size; usually with alternating small and large pores. Corners or larger polygonal pores armed with spines, which are centrifugally or obliquely directed. The ring may remain at this stage or may build a few larger pores outside the smaller ones. In both cases, margin of ring is spiny, frayed, and very irregular. Velum absent.

Material: five specimens in samples 04-ELB-4 and 04ELB-5.

Holotype: Fig. 14r, Musée de Géologie Lausanne, No. 74422.

Dimensions (in $\mu \mathrm{m}$, based on three specimens): Diameter of inner ring 325-408 (holotype 408), diameter of outer ring without teeth 200-218 (holotype 204). 
Remarks: Ploechingerella irregularis n. sp. differs from $P$. subcerniculum n. sp. in having pores of various size and incomplete second rows of pores. The specimens with the first row of pores incomplete and the test among the bars and arches of the initial spicule incompletely formed or absent (Fig. 14n, p) are considered young specimens. By this feature they resemble some specimens of the species $P$. elbistanensis n. sp. from which they only differ in having pointed spines.

Etymology: From the Latin irregularis-irregular, because of the very irregular pore size and arrangement.

Range and occurrence: Middle Carnian, Tetraporobrachia riedeli Zone, Köseyahya section, Elbistan, SE Turkey, and Zulla Formation, Wadi Bani Khalid, Oman; early Late Carnian, Karpenission, Greece, and Kiso Mountains, Japan.

\section{Ploechingerella subcerniculum Dumitrica \& Tekin n.} sp. (Figs. 14u, v, 15a, b)

Description: Initial skeleton with $\mathrm{MB}, \mathrm{A}, \mathrm{V}, \mathrm{L}_{\mathrm{r}}, \mathrm{L}_{\mathrm{l}}, \mathrm{l}_{\mathrm{r}}, \mathrm{l}_{1}$ a very short $\mathrm{D}$, and arches $\mathrm{AV}, \mathrm{AL}, \mathrm{Al}, \mathrm{LV}$ and $\mathrm{Ll}$, and connected to the ring by three rays representing the prolongations of $\mathrm{A}, \mathrm{L}_{\mathrm{r}}$ and $\mathrm{L}_{\mathrm{l}}$. Pores rounded, polygonal to subcircular, alternately disposed in a maximum of three rows, the first with 17-20, with a maximum for 18-19, the external one usually incomplete and rather irregular. Velum always present but incompletely preserved, connected to first ring by a number of bars which is practically equal with the number of pores of first row.

Material: 15 specimens.

Holotype: Fig. 14u, v, Musée de Géologie Lausanne, No. 74423.

Dimensions (in $\mu \mathrm{m}$, based on nine specimens): Diameter of inner ring 167-221 (holotype 221), diameter of outer ring without teeth 259-428 (holotype 428).

Remarks: Ploechingerella subcerniculum n. sp. resembles very much $P$. multiperforata Kozur \& Mostler 1972 by having a wide perforate ring but differs from it in having only three connecting rays between the medullary shell and ring. Although for some species the presence or absence of connecting rays aligned with secondary spines do not seem to play an important role in taxonomy, their constant absence in our samples and equally constant presence in the samples from Austria (Kozur \& Mostler 1972, 1981; Lahm 1984) seem to prove that this character indicates the presence of two distinct species.

Etymology: From the Latin subcerniculum-sieve.

Range and occurrence: Middle Carnian, Tetraporobrachia haeckeli Zone, Köseyahya section, Elbistan, SE Turkey.
Ploechingerella torquis Dumitrica \& Tekin n. sp.

(Fig. 15c-h)

Description: Initial skeleton as for the genus, connected to the ring by three rays representing the prolongations of bars $\mathrm{A}, \mathrm{L}_{\mathrm{r}}$, and $\mathrm{L}_{\mathrm{l}}$. Bars 1 of the initial spicule short, not prolonged beyond medullary shell. Ring double with a row of about 18-21 rounded, quadrangular, or elliptical pores. Periphery of second ring bearing small teeth arising from the intervals between radial bars separating the pores. There are commonly one or two teeth in each interval. Rarely, very few teeth may be connected distally forming small additional pores. Test commonly without velum, rarely with an incipient one.

Material: eleven specimens (four in sample 04-ELB-1, three in sample 04-ELB-2, one in sample 04-ELB-4, one in sample 04-ELB-5).

Holotype: Fig. 15c-g, Musée de Géologie Lausanne, No. 74424.

Dimensions (in $\mu \mathrm{m}$, based on six specimens): Diameter of inner ring 170-224 (holotype 205), diameter of outer ring without teeth 270-349 (holotype 314).

Remarks: This new species is rather similar to $P$. elbistanensis $\mathrm{n}$. $\mathrm{sp}$. from which it differs in having three instead of five rays between the medullary shell and the ring and in that no marginal teeth are aligned with the radial bars separating the pores. By the number of rays connecting the initial skeleton to the ring and by the presence, sometimes, of small pores outside the outer ring of pores, this species seems to be closely related to $P$. subcerniculum $\mathrm{n}$. sp. and even considered as representing younger ontogenetic stages of the latter. However, the rather well-formed margins prove that it is an independent species.

Etymology: From the Latin torquis-necklace.

Range and occurrence: Middle Carnian, Tetraporobrachia haeckeli Zone, Köseyahya section, Elbistan, SE Turkey; early late Carnian, Zulla Formation, Wadi Bani Khalid, Oman.

Ploechingerella undomarginata Dumitrica \& Tekin n. sp. (Fig. 15i-k)

Description: Initial skeleton with $\mathrm{MB}$, bars $\mathrm{A}, \mathrm{L}_{\mathrm{r}}, \mathrm{L}_{\mathrm{l}}, \mathrm{l}_{\mathrm{r}}, \mathrm{l}_{1}$, and a very short $\mathrm{D}$, and arches $\mathrm{AV}, \mathrm{AL}, \mathrm{Al}, \mathrm{VL}$, and $\mathrm{Ll}$. Central shell connected distally to the ring by five rays corresponding to $\mathrm{A}$, two $\mathrm{L}$, and two 1 . Ring double, one internal and one peripheral, separated by a row of some 18-20 large subsquarish or trapezoidal pores. Outer ring smooth, undulate, with arches corresponding to pores and constrictions to radial bars separating the pores. Without marginal spines. Portion inside the inner ring closed on both sides by a thin discoidal test with polygonally-framed 


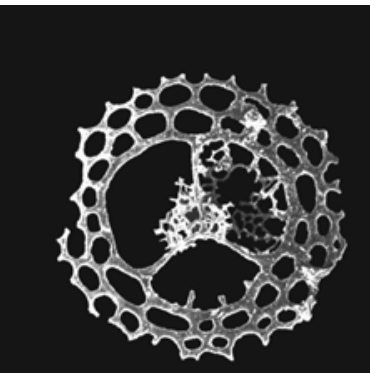

A

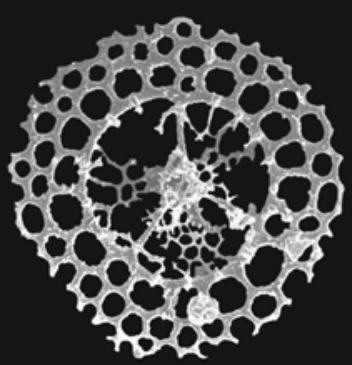

$\mathrm{B}$

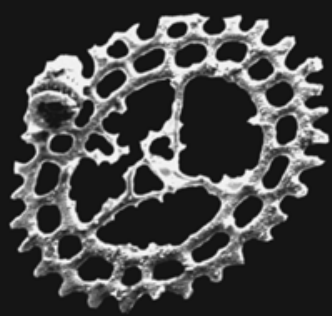

C

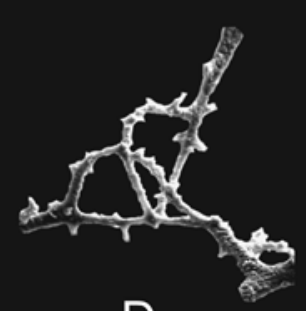

D
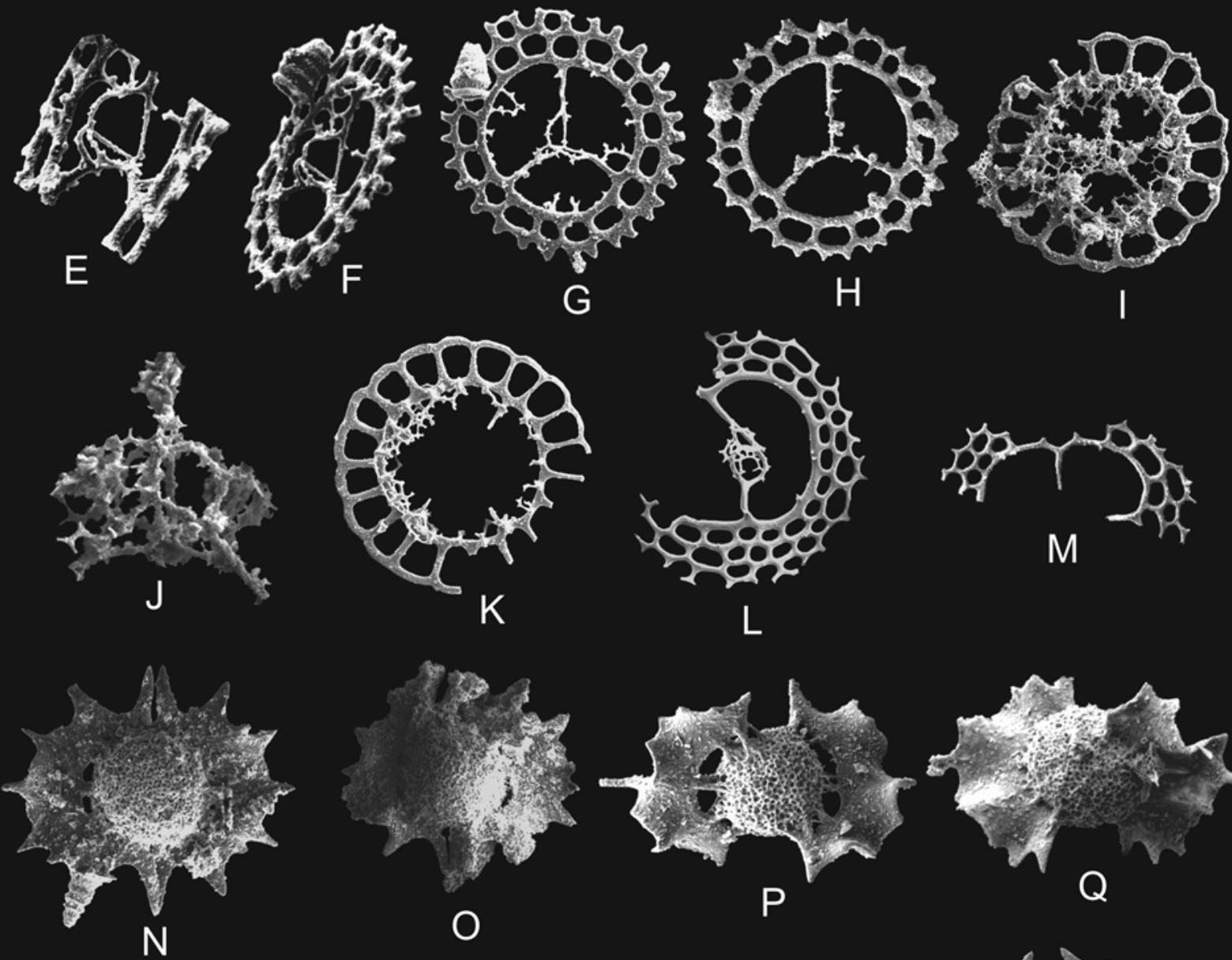

$\mathrm{O}$

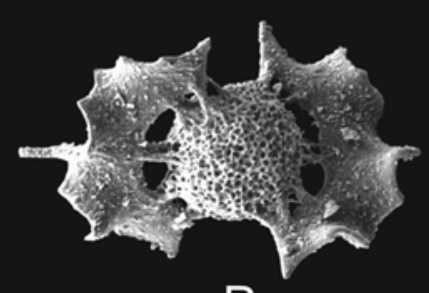

$\mathrm{P}$

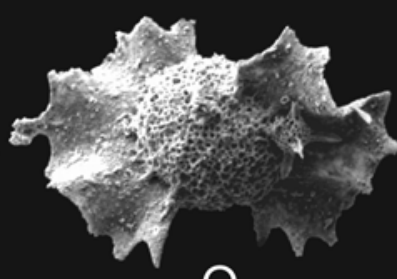

Q

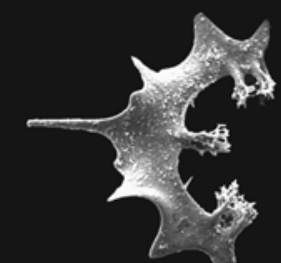

$\mathrm{R}$
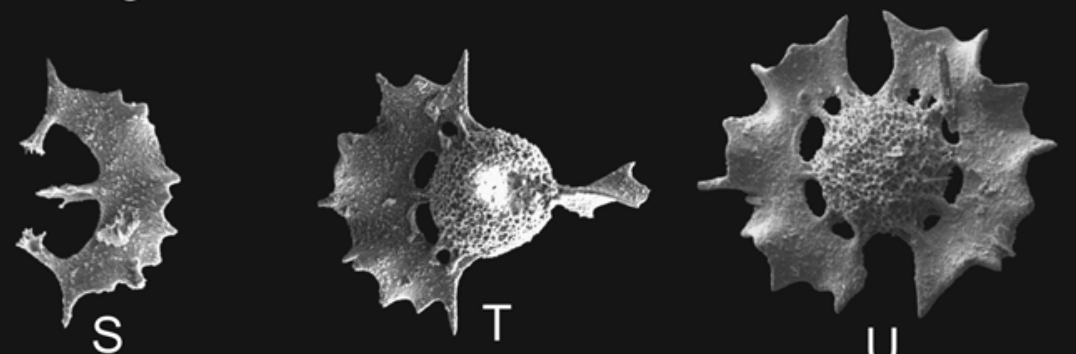

Fig. 15 a, b Ploechingerella subcerniculum Dumitrica \& Tekin n. sp., paratypes, 04-ELB-2, scale bar $=100 \mu \mathrm{m}$. c-h Ploechingerella torquis Dumitrica \& Tekin n. sp.; c-g holotype, 04-ELB-4; d, e details of the initial spicule; scale bar $=90,40,50,90$, and $90 \mu \mathrm{m}$, respectively; h paratype, 04-ELB-5, scale bar $=90 \mu \mathrm{m}$. i-k Ploechingerella undomarginata Dumitrica \& Tekin n. sp.; i, j holotype, 04ELB-2; $\mathbf{j}$ detail of the initial spicule, scale bar $=100$ and $40 \mu \mathrm{m}$,

respectively; $\mathbf{k}$ paratype, 04-ELB-5, scale bar $=100 \mu \mathrm{m}$. I, m Ploechingerella sp. A; 1 04-ELB-1; m 04-ELB-5; scale bar $=100 \mu \mathrm{m}$. n-u Angulocircus laterospinosus Lahm; n 04-ELB5; o 04-ELB-3, scale bar for both figures = $120 \mu \mathrm{m} ; \mathbf{p}$ 04-ELB-1; $\mathbf{q}$ 04-ELB-2; r-u 04-ELB-1; scale bar $=100,100,100,100,100$ and $110 \mu \mathrm{m}$, respectively 
pores of irregular size and arrangement. Shell connected to the ring by bars arising on both sides of the ring from the intervals between the radial bars separating the peripheral pores. Usually on each side there is only one connecting bar in each interval.

Material: seven specimens, of which three entire in samples 04-ELB-1, 04-ELB-2, and 04-ELB-4.

Holotype: Fig. 15i, j, Musée de Géologie Lausanne, No. 74425 .

Dimensions (in $\mu \mathrm{m}$, based on three specimens): Diameter of inner ring 190-236 (holotype 190), diameter of outer ring 335-374 (holotype 335).

Remarks: This species differs from all the other species of the genus Ploechingerella in having a single row of peripheral pores and an undulate margin, without peripheral spines.

Etymology: According to its undulate margin.

Range and occurrence: Middle Carnian, Tetraporobrachia haeckeli Zone, Köseyahya section, Elbistan, SE Turkey.

\section{Ploechingerella sp. A (Fig. 151, m)}

Remarks: This taxon, from which we have only two fragments, resembles very much Ploechingerella subcerniculum $\mathrm{n}$. sp. from which it differs in being more delicate, in having the first ring of pores smaller and elongate in the circumferential direction, and in not having an inner velumlike shell. Because the shell is not complete we ignore the number of rays between the central shell and the ring.

Range and occurrence: Middle Carnian, Tetraporobrachia haeckeli Zone, Köseyahya section, Elbistan, SE Turkey.

\section{Superfamily Saturnaliacea Deflandre 1953}

Remarks: We cannot use the emended diagnosis of the superfamily by Kozur and Mostler (1972), as mentioned in Kozur (2008) for the simple reason that in that paper, which represents the first record of many Triassic saturnaliaceans, the two authors included also in this group ringbearing genera that have subsequently been assigned to other groups of Radiolaria. Moreover, in the same paper they included a part of the saturnalids under the family Heliodiscidae. The high artificiality of this classification based more on test shape than on how the test is constructed was later criticized by Pessagno in Pessagno et al. (1979) who presented a revised classification. The Saturnaliacea were again emended by Kozur \& Mostler (1983) who recognized that what they had considered before as saturnalids are in fact of polyphyletic origin, a part of them belonging to the new order Entactinaria, another part to Spumellaria, and that the true saturnalids are spumellarians. The last emendation of this group was made by the two authors several years later (Kozur \& Mostler 1990) on the occasion of the discovery of a late Hettangian fauna. In this paper the taxonomy of the whole group was largely discussed and improved, although we are still far from a generally acceptable taxonomy that should reflect the evolution and the phylogenetic relationships of the Saturnaliacea. There are still many unknown factors that should find a solution in future studies, as for example: stratigraphical range and paleogeographical distribution of species and genera, initial structure of Triassic taxa, origin of the group, etc.

As concerns the initial structure, Dumitrica (1985), Dumitrica in De Wever et al. (2001), and Dumitrica \& Zügel (2008) showed that all Jurassic, Cretaceous and Cenozoic saturnaliaceans start their skeletal morphogenesis from a special initial skeleton with a median bar, four rays, and four primary pores, that would suggest an entactinarian structure and that is the primary element of a heteropolar microsphere. No such a structure has so far been found in the Triassic saturnaliaceans and the Oertlispongidae, their supposed forerunners, although Kozur \& Mostler (1990) mentioned that "a tiny microsphere with large pores is always present" in both groups. This fact is inexact, because nobody has yet seen and illustrated the first shell (microsphere) of the Oertlispongidae and of the Triassic Saturnaliacea, because of the poor preservation or to the complete or partial dissolution of the spongy central shell of the species so far known. Sections that the senior coauthor (PD) made in many superficially very well preserved specimens of these groups of Triassic radiolarians gave no positive result (see for example Fig. 16r, s).

For this type of "microsphere", which is never spherical but sack-like and heteropolar, having at one end the initial spicule and the initial tetrapetaloid structure bordered by the so-called primary ring (Dumitrica 1985), we introduce herein the term microbursa, (plural microbursas or microbursae), from the Medieval Latin bursa-bag, purse and micro-small. This new term can also be applied to the so-called microspheres of the Hindeosphaeridae, Hexalonchidae, Rhizosphaeridae, some Pentactinocarpidae, etc., which are also heteropolar, sack-like, with the spicule at the apical part and the sack-like skeleton at the antapical part. The term "microsphere" should be applied to the spherical or globular first shells of Spumellaria the size of which is generally not larger than $50 \mu \mathrm{m}$.

As concerns the origin of the Saturnaliacea, Kozur \& Mostler (1983) stated that the superfamily originated in the Oertlispongidae, and that the genus Angulocircus Lahm is a transitional form between this family and the ring-bearing Saturnaliacea. They even mentioned (Kozur \& Mostler 1990) that the "highly evolved Oertlispongidae are connected by all transitions with the Parasaturnalidae". It is therefore strange that Kozur et al. (2007) and especially 


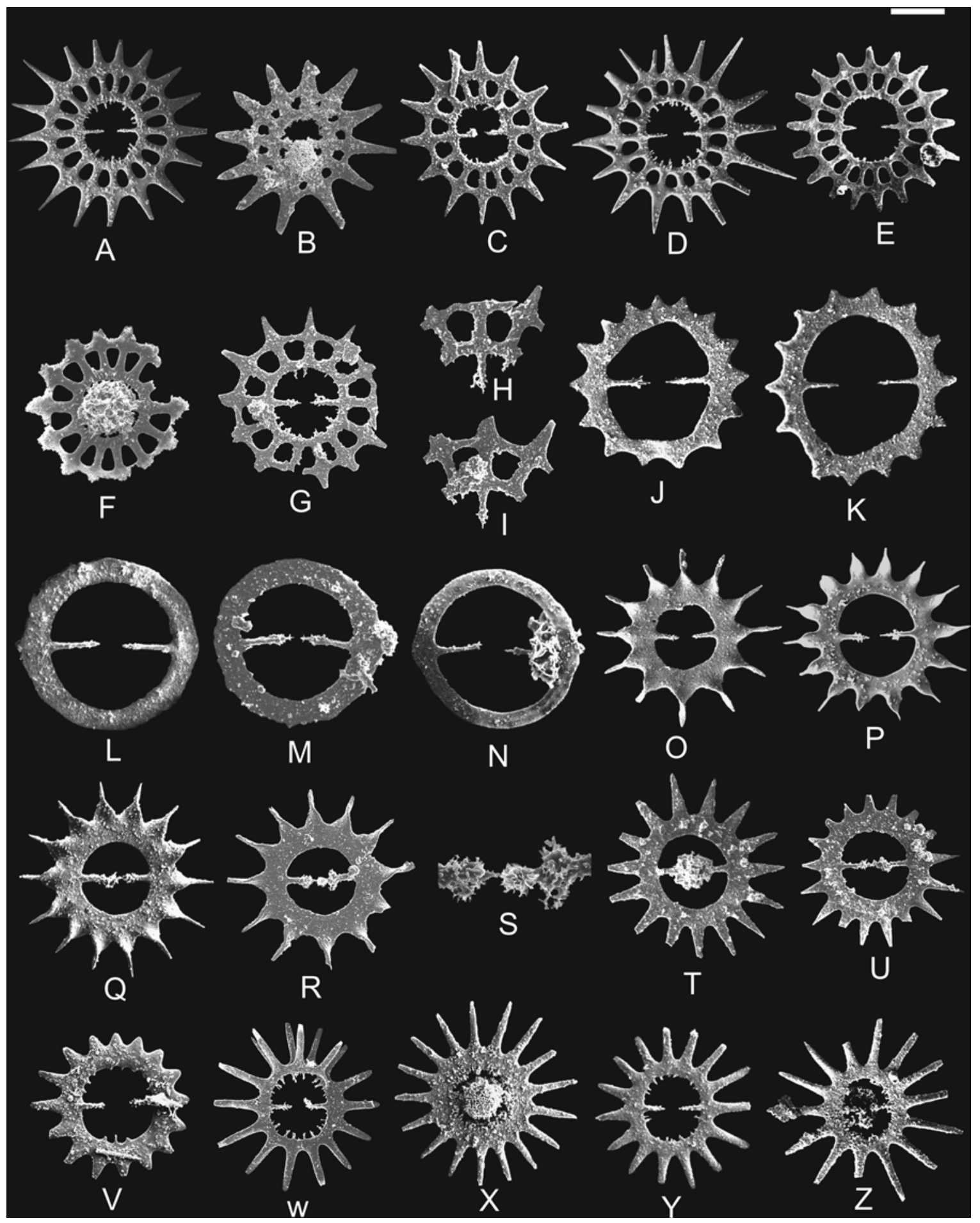

Fig. 16 a-i: Heliosaturnalis magnus Kozur \& Mostler; a 04-ELB-1; b 04-ELB-5; c 04-ELB-2; d 04-ELB-1, e BR917; f 04-ELB-2; g-i 04ELB-2, specimen broken during skeletal morphogenesis and partly repaired; $\mathbf{h}$, $\mathbf{i}$ details at the two ends of the polar spines, see also Fig. 9; scale bar $=150,130,140,150,130,120,120,90$ and 90, respectively. j-k Palaeosaturnalis brevispinosus (Kozur \& Mostler), 04-ELB-2, scale bar $=90 \mu \mathrm{m}$. l-n Palaeosaturnalis edentatus Dumitrica \& Tekin n. sp.; I holotype, 04-ELB-4; m, n paratypes; m 04-ELB-4; n 04-ELB-2; scale bar for all figures $=80 \mu \mathrm{m}$. o-s
Palaeosaturnalis hugluensis Tekin, all specimens are from 04-ELB-2; $\mathbf{s}$ detail of $\mathbf{r}$ showing that the microsphere is recrystallized and replaced by an aggregate of foliaceous crystals; scale bar $=140,120$, 140, 130 and $70 \mu \mathrm{m}$, respectively. t-v Palaeosaturnalis triassicus (Kozur \& Mostler); t, u 04-ELB-5; v 04-ELB-1; scale bar for all specimens $=120 \mu \mathrm{m}$. $\mathbf{w}-\mathbf{z}$ Pseudoheliodiscus primitivus (Kozur \& Mostler); w specimen with open ring, 04-ELB-2, same as Fig. 9; $\mathbf{x}$ 04-ELB-5; y, $\mathbf{z}$ 04-ELB-2; scale bar $=140,160,140$ and $150 \mu \mathrm{m}$, respectively 
Kozur (2008), without any explanation, derive the new family Archaeoacanthocircidae Kozur, Moix \& Ozsvart of Triassic saturnalids from the genus Dumitricasphaera Kozur \& Mostler, a genus with three-bladed polar spines. Should we understand from this that Kozur (2008) considers again the Saturnaliacea as a polyphyletic group, with the Parasaturnalidae derived from the Oertlispongidae and the Archaeoacanthocircidae from the genus Dumitricasphaera Kozur \& Mostler, which is not at all an oertlispongid? Or that he considers also the Parasaturnalidae have as forerunner the family Oertlispongidae? He gave no direct answers to these two questions but he seems to exclude the origin of the Saturnaliacea in the Oertlispongidae, when he writes that the origin of the Archaeoacanthocircidae is unlikely to be in the oertlispongid genera Scutispongus Kozur \& Mostler or Steigerispongus Kozur \& Mostler, as Dumitrica \& Hungerbühler (2007) had proposed, because they "have one very large differentiated polar spine and an opposite polar spine that is tiny and needle-like and surely would not have evolved into a big differentiated polar spine like the main polar spine present in Archaeoacanthocircus" (Kozur 2008: 4, col. 2). In this case, it is difficult to understand where to place Angulocircus Lahm, with its two big, flat, and equal polar spines, which was the key genus in the previous interpretation of the origin of the Saturnaliacea in the Oertlispongidae (Kozur \& Mostler 1990).

In our opinion, and with out current knowledge, the origin of the Saturnaliacea seems, however, to be in the Oertlispongidae by the duplication of the main spine and fusion of the lateral ends of the wings of the two spines to form a ring. It is also possible that their ring, which is perfect in the oldest species, comes from the entactinarian genera Austrisaturnalis Kozur \& Mostler or Hungarosaturnalis Kozur \& Mostler, with species frequent in the late Ladinian (middle late Longobardian) (Mostler \& Krainer 1993/94), by a horizontal gene transfer to the Oertlispongidae with foliaceous main spine, also frequent at the same stratigraphic level (Dumitrica 1982; Kozur and Mostler 1996). Their origin in the genus Berlahmium Dumitrica \& Tekin in Dumitrica \& Hungerbühler (2007) seems to be impossible, because of the three-bladed polar spines characteristic of this genus.

The superfamily could be subdivided into three families:

(a) Heliosaturnalidae Kozur \& Mostler 1972, with equatorial ring, polar spines and multi-layered spongy shell; ring flat, foliaceous or elliptical in cross section, rarely three or four-bladed, usually circular, but also subquadratic or rarely hexagonal, rarely open in the equatorial area. Early Carnian to Bajocian.

(b) Saturnalidae Deflandre 1953, with equatorial ring and no polar spines; ring circular to elliptical, elongated in the perpendicular direction to polar rays, flat or elliptical in cross section, or, most frequently, three or four-bladed. Shell spongy, multi-layered to latticed and two-layered. The oldest species, namely those occurring in the middle-late Norian and Rhaetian (Kozur \& Mostler 1972; Carter 1993), have transitional morphology, with still circular ring, less pronounced saddle at the junction of the polar rays to the ring, and unstable position of the polar rays relative to the two peripolar spines. Middle-late Norian to Recent.

(c) Axoprunidae Dumitrica 1985, without equatorial ring, with two polar spines and latticed cortical shell. Cenozoic.

This subdivision seems to be rather logical. It would mark the three big stages in the evolution of Saturnaliacea:

(a) appearance of the polar spines synchronous with that of the ring;

(b) disappearance of the polar spines; and

(c) disappearance of the ring.

We do not intend to discuss herein the subdivision of the first two families into subfamilies. A sketch of such a subdivision can be found in two recent papers (O'Dogherty et al. 2009a, b). It is much simpler than that by Kozur \& Mostler (1990).

Range: Early Carnian to Recent.

Family Heliosaturnalidae Kozur \& Mostler 1972, revised herein

\section{Type genus: Heliosaturnalis Kozur \& Mostler 1972}

Revised definition: Saturnaliacea with polar spines.

Remarks: We include in this family all saturnaliacean genera with polar spines. Unlike Kozur \& Mostler (1990), we think that this is the most important character that can distinguish the first two big stages in the evolution of Saturnaliacea. It appeared in the early Julian (Tritortis kretaensis Zone), at the same time as the first appearances of the ring, and disappeared at the end of the Bajocian (Yao 1997). We do not take into account in this discussion the genus Saturnalium Haeckel 1887, for which Kozur \& Mostler (1990) erected a new family. This genus, represented by a single species and specimen, has polar spines, but should remain questionable in the present state of knowledge, because since its publication it has no longer been recorded in the Cenozoic, Cretaceous, and Jurassic, and because by its ring it has a pre-Jurassic morphology. In fact its branched spines resemble very much the spines of the late Triassic Spongosaturnalis kahleri Kozur \& Mostler 1972. The introduction of a special family in this case does not add more knowledge to the taxonomy and evolution of the Saturnaliacea. 
At the level of family we give no special taxonomic value to the presence or absence of auxiliary or subsidiary rays and to the shape of the cross-section of the ring that can be completely flat or elliptical, or may be three or fourbladed (Octosaturnalis Kozur \& Mostler 1990).

Range: Early Carnian (Tritortis kretaensis Zone) to Bajocian, cosmopolitan.

Genus Angulocircus Lahm 1984

1984 Angulocircus n. gen. Lahm: 99.

Type species: Spongosaturnalis bipartitus Kozur \& Mostler 1972: 32.

Remarks: Although Kozur \& Mostler (1990) placed this genus in the Oertlispongidae for the reason that the two parts of the ring are not yet fused, Angulocircus is much closer to the Saturnaliacea because it has two opposite and equal main spines, as in the Saturnaliacea. As is known, the Oertlispongidae have a single main spine. Its duplication in Angulocircus, if the genus does come from this family, is an important qualitative jump in the evolution of these radiolarians (Dumitrica \& Hungerbühler 2007). It also differs from the Oertlispongidae in having the wings interconnected with the spongy skeleton by auxiliary rays, as in many Triassic and early Jurassic Saturnaliacea.

Range: Early to middle Carnian (Tritortis kretaensis Zone to Tetraporobrachia haeckeli Zone).

Angulocircus laterospinosus Lahm 1984 (Fig. 15n-u)

1984 Angulocircus laterospinosus Lahm: 101, pl. 18 Fig. 7.

Description: Central shell spherical, smooth, smaller than or equal to the inner diameter of the wings. Wings broad, both in the same plane or rotated to one another up to $90^{\circ}$. They are undulate, and the number of complete undulations is always three. Each wing connected to shell by the polar ray and by two or more auxiliary rays. External margin with a variable number of wide indentations and generally short, triangular teeth. Polar spines very short, almost undistinguished, to long and pointed.

Material: 12 specimens.

Remarks: This species is very well distinguished from all the other species of the genus by its undulated wings. The number of complete undulations is very constant, only the size and number of denticulations of the external margin and the length of the polar spines differ. These characteristic undulations are visible with the holotype of Angulocircus laterospinosus Lahm although they were not mentioned in the original description. This species proves that the position of the two halves relative to each other is variable in the same species and only the morphology of the ring-halves is important. It suggests that Angulocircus longispinosus Lahm should be a junior synonym of $A$. bipartitus (Kozur \& Mostler) because the difference between these species consists only in the reciprocal position of the two ring-halves: rotated under a certain angle in the former species and coplanar in the latter. The same rotation occurs also as intraspecific variation in other radiolarian species with two opposite, flat or curved spines, as, for example, in Spongotortilispinus carnicus Kozur \& Mostler 1979 and in one new middle Carnian species of Berlahmium Dumitrica \& Tekin, 2007 (in Dumitrica \& Hungerbühler 2007), which will be described in a forthcoming paper.

Range and occurrence: Middle Carnian, Tetraporobrachia haeckeli Zone: Großreifling, Austria; Köseyahya section, Elbistan, SE Turkey.

Genus Heliosaturnalis Kozur \& Mostler 1972

1972 Heliosaturnalis n.gen. Kozur \& Mostler: 27.

Remarks: Although several species were originally described within this genus, this taxon is herein considered monospecific (see below).

Range and occurrence: Same as the type species.

Heliosaturnalis magnus Kozur \& Mostler 1972

(Figs. 6, 16a-i)

1972 Heliosaturnalis magnus Kozur \& Mostler: 28, pl. 2 Fig. 6; pl. 4 Fig. 4.

1984 Heliosaturnalis magnus Kozur \& Mostler. Lahm: 102, pl. 18 Fig. 9.

1972 Heliosaturnalis ? imperfectus Kozur \& Mostler: 28, pl. 2 Fig. 1.

1984 Heliosaturnalis imperfectus Kozur \& Mostler. Lahm: 102, pl. 18 Fig. 8.

1972 Heliosaturnalis longispinosus Kozur \& Mostler: 28, pl. 2 Fig. 3.

1984 Heliosaturnalis longispinosus Kozur \& Mostler. Lahm: 103, pl. 18 Fig. 10.

1972 Heliosaturnalis transitus Kozur \& Mostler: 29, pl. 2 Fig. 7; pl. 4 Fig. 6.

1984 Heliosaturnalis transitus Kozur \& Mostler. Lahm: 103, pl. 18 Fig. 11.

1999 Heliosaturnalis transitus Kozur \& Mostler. Tekin: 108, pl. 16 Fig. 1.

1984 Heliosaturnalis sp. Lahm: 104, pl. 18 Fig. 12.

Description: Test spongy, discoid, completely filling the inner ring to which it is connected by numerous auxiliary rays. Ring with $12-19$ spines, more frequently $13-17$ with a maximum of 14 spines. Spines long, interconnected at a certain distance from the inner ring by a second ring forming between it and the first ring a row of pores equal in number to the number of spines. Pores trapezoidal to elliptical. Second ring may be incomplete in young ontogenetic stages. 
Remarks: We include in this species all species initially erected by Kozur \& Mostler (1972), because, in our opinion, they represent variations of a single species; they come from the same locality and the same stratigraphic level, and the differences between them are minimal. $H$. imperfectus, with an incomplete second ring, is nothing other than a young ontogenetic stage of $\mathrm{H}$. magnus. These young stages are interesting because they show that the second ring is built in the last ontogenetic stage by tangential growth, namely by bilateral bridge growth from each spine at the same distance from the primary ring. In this respect the specimen illustrated in Figs. 6 and $16 \mathrm{~g}-\mathrm{i}$ is very interesting paleobiologically. It shows that the first ring broke in the vicinity of one polar spine during the growth of the skeleton, but that it was later repaired. Because of the fracture the two ends of the ring shifted sensibly from the equatorial plane so that during the repair process they lengthened a little, superposed, and coalesced. A similar case was illustrated by Anderson (1983: 144, Fig. 2-24b) with the nassellarian Callimitra sp. This fracture shifted both polar spines relative to the equatorial plane of the ring, so that when the second ring started building, the lateral branches of both spines could not perfectly meet the branches of the adjacent spines. Three of these branches remained as lateral spinules, superposed, and probably partly coalesced. The fourth branch fused with the spinule of the adjacent spine, but the place of their fusion is marked by a bend.

Material examined: 35 specimens.

Range and occurrence: Middle Carnian, Tetraporobrachia haeckeli Zone, to early Late Carnian, Spongotortilispius moixi Zone: Göstling and Großreifling, Austria; Bozkir, Konya, Köseyahya section, Elbistan, Turkey; Zulla Formation, Wadi Bani Khalid section, Oman.

Genus Palaeosaturnalis Donofrio \& Mostler 1978 emend. Kozur \& Mostler 1981

1978 Palaeosaturnalis n. gen. Donofrio \& Mostler: 33.

1981 Palaeosaturnalis Donofrio \& Mostler 1978 emend. Kozur \& Mostler: 55.

Type species: Spongosaturnalis triassicus Kozur \& Mostler 1972: 40.

Range: Early Carnian (Tritortis kretaensis Zone) to Bajocian.

Palaeosaturnalis brevispinosus (Kozur \& Mostler 1972) (Fig. 16j, k)

1972 Spongosaturnalis brevispinosus Kozur \& Mostler: 33, pl. 1 Fig. 7.

1981 Palaeosaturnalis brevispinosus (Kozur \& Mostler). Kozur \& Mostler: 55.
Material: ten specimens.

Remarks: Our specimens are perfectly similar to the holotype, and number of spines varies between 13 and 17 .

Range and occurrence: Middle Carnian, Tetraporobrachia haeckeli Zone: Großreifling, Austria; Köseyahya section, Elbistan, SE Turkey.

Palaeosaturnalis edentatus Dumitrica \& Tekin n. sp. (Fig. $161-n$ )

(1997) Saturnalidae gen. et sp. indet. Sugiyama: Fig. 51. 4.

Description: Ring circular, flat, without peripheral spines or with spines visible as faint undulations of the periphery. Polar spines reduced to two very weak expansions of the ring.

Material: five specimens in samples 04-ELB-2, 04ELB-4, and 04-ELB-5.

Holotype: Fig. 16 1, Musée de Géologie Lausanne, No. 74426.

Dimensions (in $\mu \mathrm{m}$, based on four specimens): Inner diameter of ring 161-185 (holotype 161), outer diameter of ring 223-65 (holotype 225).

Remarks: P. edentatus n. sp. differs from all the other species of the genus by missing spines. When traces of spines are visible there are approximately five on each ring half. The specimen illustrated by Sugiyama (1997) from the upper Norian strata of Japan is perfectly similar to our specimens. However, given the long time interval between the two occurrences it is possible that his specimen comes from another species by the same process of reduction of spines.

Etymology: From the Latin edentatus-without teeth.

Range and occurrence: Middle Carnian, Tetraporobrachia haeckeli Zone, Köseyahya section, Elbistan, SE Turkey; late Norian, Japan.

Palaeosaturnalis hugluensis Tekin 1999 (Figs. 7, 160-s)

1999 Palaeosaturnalis hugluensis Tekin: 110, pl. 16 Figs. 7-9.

Description: Shell small, its diameter about half the inner diameter of ring. Ring flat and broad with 11-17 triangular spines, which are sinistrally twisted up to $90^{\circ}$. Both polar and circumferential spines equal and equally spatiated.

Material: More than 100 specimens.

Remarks: The species is rather frequent in the region studied. Number of spines varies between 11 and 17, with most having 14, the distribution of their number conforming very well with a Gaussian curve (Fig. 7).

Range and occurrence: Middle Carnian, Tetraporobrachia haeckeli Zone, Bozkir, Konya and Köseyahya section, Elbistan, Turkey. 
Palaeosaturnalis triassicus (Kozur \& Mostler 1972)

(Fig. 16t-v)

1972 Spongosaturnalis triassicus Kozur \& Mostler: 40, pl.

1, Fig. 10; pl. 4, Figs. 1, 2. non 1979 Spongosaturnalis triassicus Kozur \& Mostler.

De Wever et al.: 81, pl. 2 Fig. 2.

1981 Palaeosaturnalis triassicus (Kozur \& Mostler).

Kozur \& Mostler: 5.

1983 Palaeosaturnalis triassicus (Kozur \& Mostler).

Kozur \& Mostler: pl. 6 Fig. 2.

1984 Palaeosaturnalis triassicus (Kozur \& Mostler).

Lahm: 97, pl. 17 Fig. 11.

1990 Palaeosaturnalis triassicus (Kozur \& Mostler).

Budai and Dosztaly: pl. 2 Fig. 1.

1999 Palaeosaturnalis triassicus (Kozur \& Mostler).

Tekin: 111, pl. 17 Figs. 6-7.

1999 Palaeosaturnalis triassicus (Kozur \& Mostler).

Bragin and Krylov: 555, Fig. 9a, b, e.

2007 Palaeosaturnalis triassicus (Kozur \& Mostler).

Bragin: 993, pl. 9 Figs. 2, 3.

2002a Palaeosaturnalis triassicus (Kozur \& Mostler).

Wang et al.: 220, pl. 2 Figs. 1-3.

2002b Palaeosaturnalis triassicus (Kozur \& Mostler).

Wang et al.: 329, pl. 1 Fig. 18.

2005 Palaeosaturnalis triassicus (Kozur \& Mostler).

Feng et al.: 245, 247, pl. 2 Fig. 18.

1984 Palaeosaturnalis cf. triassicus (Kozur \& Mostler).

Lahm: 98, pl. 17 Fig. 12.

non 1982 Acanthocircus triassicus (Kozur \& Mostler).

De Wever: 207, pl. 13 Fig. 10.

Material: seven specimens.

Range and occurrence: Middle Carnian-middle No-

rian; Göstling, Grossreifling, Austria; Balaton, Hungary;

Kemer, Antalya and Köseyahya section, Elbistan, Turkey;

Mamonia Complex, Cyprus; Baja, California; Tibet, China; northwest Thailand; Zulla Formation, Wadi Bani Khalid, Oman.

Genus Pseudoheliodiscus Kozur \& Mostler 1972

emend. Pessagno, in Pessagno et al. 1979

1972 Pseudoheliodiscus n. gen. Kozur \& Mostler: 24.

1979 Pseudoheliodiscus Kozur \& Mostler, 1972. Pessagno in Pessagno et al.: 169.

Type species: Pseudoheliodiscus riedeli Kozur \& Mostler 1972.

Pseudoheliodiscus primitivus (Kozur \& Mostler 1972)

(Figs. 8, 9, 16w-z)

1972 Spongosaturnalis primitivus Kozur \& Mostler: 38, pl. 2 Fig. 10; pl. 4 Fig. 5, 9.
?1979 Spongosaturnalis primitivus Kozur \& Mostler. De Wever et al.: 80, pl. 1 Fig. 10.

?1982 Pseudoheliodiscus primitivus (Kozur \& Mostler). De Wever: 220, pl. 19 Fig. 6.

1999 Pseudoheliodiscus primitivus (Kozur \& Mostler). Tekin: 115, pl. 19 Fig. 3.

1993/94 Spongosaturnalis primitivus Kozur \& Mostler.

Mostler \& Krainer: pl. 9 Fig. 11.

Material: More than 50 specimens.

Remarks: What seems to distinguish this species from Palaeosaturnalis triassicus (Kozur \& Mostler), besides the presence of many auxiliary spines, is that the spines are thinner and their sides are commonly subparallel for most of their length. Many spines are also slightly sinistrally tilted. The auxiliary spines are usually very short or even practically absent, depending probably on the size of central spongy shell relative to the inner diameter of the ring. This proves the artificiality of the separation, in some cases, of the genus Pseudoheliodiscus from Palaeosaturnalis. The number of spines varies between 13 and 17, with most specimens having 16 spines (Fig. 8). What we found interesting with this species is an anomalous specimen with one open side (Figs. 9, 16w). Similar cases have been discussed and illustrated with the early Tithonian Saturnalidae from the Solnhofen area (Dumitrica \& Zügel 2008) and prove that the Triassic Saturnalidae built their ring in the same manner as the Jurassic and Cretaceous ones.

Range and occurrence: Early to middle Carnian (Tritortis kretaensis Zone to Tetraporobrachia haeckeli Zone); Göstling and Großreifling, Austria; Karpennission, Greece; Palazzo Adriano, Sicily; Bozkir, Konya and Köseyahya section, Elbistan, Turkey.

Acknowledgments All the photographs used in this study were taken with the CamScan electronic microscope in the Hochschule der Künste Bern, Switzerland. We are very much obliged to Dr Nadim C. Scherrer for his kindness and permission to use this microscope any time we needed it. The senior co-author thanks also his wife, Ruth Dumitrica, for her assistance with the preparation of some figures and for translation of the abstract. The authors are very much obliged to the two reviewers: Spela Gorican, Ljubljana, and an anonymous reviewer who read the text very carefully and made fruitful suggestions to improve it.

\section{References}

Anderson, O.R. 1983. Radiolaria. New York: Springer. 355 p.

Béchennec, F. 1987. Géologie des nappes Hawasina dans les parties orientale et centrale des Montagnes d'Oman. Ph.D. thésis, Université Pierre \& Marie Curie, Paris 6. Documents du Bureau de Recherches Géologiques et Minières, no. 127, 474 p.

Béchennec, F., R. Wyns, J. Roger, J. Le Metour, and S. Chevrel. 1992. Sultanate of Oman. Geological map of Nazwa, Sheet NF 40-07, scale 1:250, 000. Explanatory notes. Orleans: BRGM.

Bedi, Y., 2004. 1/25.000 scale Turkish geological maps, L38c2 Quadrangle. Ankara: Archive of the Geological Research 
Department, General Directorate of Mineral Research and Exploration. (unpublished).

Bedi, Y., D. Usta, M.K. Özkan, M. Beyazpirinc, H. Yildiz, and H. Yusufoglu. 2005. The tectono-stratigraphic characteristics of allochthonous sequences in Eastern Taurides. 58th Geological Congress of Turkey, Abstracts: 262-263.

Blechschmidt, I., P. Dumitrica, A. Matter, L. Krystyn, and P. Tjerk. 2004. Stratigraphic architecture of the northern Oman continental margin-Mesozoic Hamrat Duru Group, Hawasina complex, Oman. GeoArabia 9(2): 81-132.

Blome, C.D. 1984. Upper Triassic Radiolaria and radiolarian zonation from western North America. Bulletin of American Paleontology 85(318): 1-88.

Brabb, E.E. 1969. Six new Paleozoic and Mesozoic formations in east-central Alaska. USGS Professional Paper 1274-I: 9-13.

Bragin, N.Yu. 2007. Late Triassic radiolarians of southern Cyprus. Paleontological Journal 41(10): 951-1029.

Bragin, N.Yu., and K.A. Krylov. 1999. Early Norian Radiolaria from Cyprus. Geodiversitas 21(4): 539-569.

Budai, T., and L. Dosztaly. 1990. A Balaton-felvidéki Ladini képzödmények rétegtani problémai. A M. Földtani Intézet évi Jelentéze az 1988 Evröl I: 61-79, Budapest.

Carter, E.S. 1993. Biochronology and paleontology of uppermost Triassic (Rhaetian) radiolarians, Queen Charlotte Islands, British Columbia, Canada. Mémoires de Géologie (Lausanne) 11(i-iii): $1-175.21$ pls.

Carter, E.S., P.A. Whalen, and J. Guex. 1998. Biochronology and paleontology of Lower Jurassic (Hettangian and Sinemurian) radiolarians, Queen Charlotte Islands, British Columbia. Geological Survey of Canada Bulletin 496: 1-162. 27 pls.

Deflandre, G. 1953. Radiolaires fossils. In Traité de Zoologie, ed. Grassé, P.P., 1 (2): 389-436, Paris (Masson).

De Wever, P. 1982. Radiolaires du Trias et du Lias de la Téthys (Systématique, Stratigraphie). Société Géologique du Nord 7(12): 1-599.

De Wever, P., A. Sanfilippo, W.R. Riedel, and B. Gruber. 1979. Triassic Radiolaria from Greece, Sicily and Turkey. Micropaleontology 25(1): 75-110.

De Wever, P., P. Dumitrica, J.-P. Caulet, C. Nigrini, and M. Caridroit. 2001. Radiolarians in the sedimentary record. Amsterdam: Gordon and Breach Science Publishers. 533 p.

Donofrio, D.A. 1991. Radiolaria and Porifera (Spicula) from the Upper Triassic of Aghdarband (NE-Iran). In The Triassic of Aghdarband (AqDarband), NE-Iran, and its Pre-Triassic Frame, vol. 38, ed. Ruttner, A.W., 205-222. Abhandlungen der Geologische Bundes-Anstalt.

Donofrio, D.A. and H. Mostler. 1978. Zur Verbreitung der Saturnalidae (Radiolaria) im Mesozoikum der Nördlichen Kalkalpen und Südalpen. - Geologisch-Paläontologische Mitteilungen Innsbruck 7 (5): 1-55.

Dumitrica, P. 1978. Family Eptingiidae n. fam., extinct Nassellaria (Radiolaria) with sagital ring. Dari de seama ale sedintelor, Institutul de Geologie si Geofizica, Bucharest 64: 27-38.

Dumitrica, P. 1982. Triassic Oertlisponginae (Radiolaria) from Eastern Carpathians and Southern Alps. Dari de seama ale sedintelor, Institutul de Geologie si Geofizica, Bucharest 67(3): $57-74$.

Dumitrica, P. 1985. Internal morphology of the Saturnalidae (Radiolaria): systematic and phylogenetic consequences. Revue de Micropaléontologie 28(3): 181-196.

Dumitrica, P. and J. Guex. 2003. Horizontal gene transfer, a possible mechanism in convergent evolution of Radiolarian. Tenth meeting of the international association of radiolarian palaeontologists. Abstract and Programme, p. 55-56, Lausanne.

Dumitrica, P., and A. Hungerbühler. 2007. Blechschmidtia n. gen. and Tjerkium n. gen., a case of phyletic gradualism of the Triassic saturnalid Radiolaria. Bulletin de la Société vaudoise de Sciences Naturelles 90(4): 217-243. Lausanne.

Dumitrica, P., and P. Zügel. 2008. Early Tithonian Saturnalidae (Radiolaria) from the Solnhofen area (Southern Franconian Alb, southern Germany). Paläontologische Zeitschrift 82(1): $55-84$.

Ehrenberg, C.G. 1838. Über die Bildung derKreidefelsenund des Kreidemergels durch unsichtbare Organismen, 59-147. Jahrg: Abhandlungen der königlichen Academie der Wissenschaften zu Berlin. pl. 1-4.

Feng, Q., K. Malila, N. Wonganan, C. Chonglakmani, D. Helmcke, R. Ingavat-Helmcke, and M. Caridroit. 2005. Permian and Triassic Radiolaria from Northwest Thailand: paleogeographical implications. Revue de Micropaléontologie 48: 237-255.

Glennie, W.K., M.G.A. Boeuf, M.W. Hughes-Clarke, M. MoodyStuart, W. Pilaar, and B.M. Reinhardt. 1974. Geology of the Oman Mountains-part one (text). Verhandelingen Koninklijk Nederlands geologisch mijnbouwkundig Genootschap 31: 1423.

Gorican, S., J. Halamic, T. Grgasovic, and T. Kolar-Jurkovsek. 2005. Stratigraphic evolution of Triassic arc-backarc system in northwestern Croatia. Bulletin de la Société géologique de France 176(1): 3-22.

Gorican, S., E.S. Carter, P. Dumitrica, P.A. Whalen, R.S. Hori, P. De Wever, L. O'Dogherty, A. Matsuoka, and J. Guex. 2006. Catalogue and systematics of Pliensbachian, Toarcian and Aalenian radiolarian genera and species. Zalozba ZRC, ZRC SAZU $=$ ZRC Publishing, $446 \mathrm{p}$.

Haeckel, E. 1887. Report on the Radiolarian collected by H.M.S. challenger during the years 1873-76. Report on the Scientific Results of the Voyage of H.M.S. Challenger during the years 1873-76, Zoology 18: clxxxviii + 1803 p, 140 pls, London.

Kozur, H.W. 2003. Integrated ammonoid, conodont and radiolarian zonation of the Triassic and some remarks to stage/substage subdivision and the numeric age of the Triassic stages. Albertiana 28: 57-74.

Kozur, H. 2008. Blechschmidtia Dumitrica \& Hungerbühler, 2007 and Tjerkium Dumitrica \& Hungerbühler, 2007, junior synonyms of Archaeoacanthocircus Kozur, Moix \& Ozsvart, 2007. Hallesches Jahrbuch für Geowissenschaften 30: 1-9.

Kozur, H., and H. Mostler. 1972. Beiträge zur Erforschung der mesozoischen Radiolarien. Teil. 1, Revision der Oberfamilie Coccodiscacea Haeckel, 1862 emend. und Beschreibung ihrer triassischen Vertreter. Geologisch-Paläontologische Mitteilungen Innsbruck 2(8/9): 1-60.

Kozur, H., and H. Mostler. 1978. Beiträge zur Erforschung der mesozoischen Radiolarien. Teil II. Oberfamilie Trematodiscacea Haeckel 1862 emend. und Beschreibung ihrer triassischen Vertreter. Geologisch-Paläontologische Mitteilungen Innsbruck 8: $123-182$.

Kozur, H., and H. Mostler. 1979. Beiträge zur Erforschung der mesozoischen Radiolarien. Teil III. Die Oberfamilien Actinommacea Haeckel, 1862 emend., Artiscacea Haeckel, 1882, Multiarcusellacea nov. der Spumellaria und triassische Nassellaria. Geologisch-Paläontologische Mitteilungen Innsbruck 9(1-2): 1132.

Kozur, H., and H. Mostler. 1981. Beiträge zur Erforschung der mesozoischen Radiolarien. Teil IV. Thalossosphaeracea Haeckel, 1862, Hexastylacea Haeckel, 1862 emend. Petruhevskaya 1979, Sponguracea Haeckel, 1862 emend. und weitere triassische Lithocycliacea, Trematodiscacea, Actinommacea und Nassellaria. Geologisch- Paläontologische Mitteilungen Innsbruck 1: 1-208.

Kozur, H., and H. Mostler. 1982. Entactinaria subordo nov., a new radiolarian suborder. Geologisch-Paläontologische Mitteilungen Innsbruck 11(12): 399-414. 
Kozur, H., and H. Mostler. 1983. The polyphyletic origin and the classification of the Mesozoic saturnalids (Radiolaria). Geologisch-Paläontologische Mitteilungen Innsbruck 13: 1-47.

Kozur, H., and H. Mostler. 1990. Saturnaliacea Deflandre and some other stratigraphically important Radiolaria from the Hettangian of Lenggries/Isar (Bavaria, Northern Calcareous Alps). Geologisch-Paläontologische Mitteilungen Innsbruck 17: 179-248.

Kozur, H., and H. Mostler. 1994. Anisian to Middle Carnian radiolarian zonation and description of some stratigraphically important radiolarians. Geologisch-Paläontologische Mitteilungen Innsbruck 3: 39-255.

Kozur, H.W., and H. Mostler. 2006. Radiolarien aus dem Longobard der Dinariden. Hallesches Jahrbuch für Geowissenschaften 28: 23-91.

Kozur, H.W., P. Moix, and P. Ozsvart. 2007. Stratigraphically important Spumellaria and Entactinaria from the lower Tuvalian (Upper Triassic) of the Huglu Unit in the Mersin Mélange, southeastern Turkey. Bulletin de la Société vaudoise de Sciences naturelles 90(3): 175-195. Lausanne.

Lahm, B. 1984. Spumellarianfauna (Radiolaria) aus dem mitteltriassichen Buchensteiner-Schichten von Recoaro (Norditalien) und den obertriassichen Reiflingerkalken von Grossreifling (Österreich). Systematik-Stratigraphie-Münchener Geowissenschaftliche Abhandlungen Series A 1: 1-161.

Moix, P., H.W. Kozur, G.M. Stampfli, and H. Mostler. 2007. New paleontological, biostratigraphic and paleogeographic results from the Triassic of the Mersin Mélange, SE Turkey. In The Global Triassic. New Mexico Museum of Natural History and Science Bulletin, vol. 41, eds. Lucas, S.G. and J.A. Spielmann, 282-311.

Mostler, H. and K. Krainer. 1993/94. Saturnalidae Radiolarien aus dem Langobard der südalpinen Karawanken (Kärnten, Österreich). Geologisch-Paläontologische Mitteilungen Innsbruck 19: 93-131.

Müller, J. 1858. Über die Thalassicollen, Polycystinen und Acanthometren des Mittelmeers, 1-62. Jahrg: Abhandlungen der königlichen Academie der Wissenschaften zu Berlin.

O’Dogherty, L., E.S. Carter, P. Dumitrica, S. Gorican, P. De Wever, A. Hungerbühler, A.N. Bandini, and A. Takemura. 2009a. Catalogue of Mesozoic radiolarian genera. Part 1: Triassic. Geodiversitas 31(2): 213-270.

O’Dogherty, L., E.S. Carter, P. Dumitrica, S. Gorican, P. De Wever, A.N. Bandini, P.O. Baumgartner, and A. Matsuoka. 2009b. Catalogue of Mesozoic radiolarian genera. Part 2: JurassicCretaceous. Geodiversitas 31(2): 270-356.

Ogg, J.G. 2004. The Triassic period. In A geologic time scale, ed. F. Grandstein, J. Ogg, and A. Smith, 271-306. Cambridge: Cambridge University Press.
Pessagno Jr., E.A., W. Finch, and P.L. Abbott. 1979. Upper Triassic radiolaria from San Hipolito formation, Baja California. Micropaleontology 25(2): 160-197.

Riedel, W.R. 1967. Subclass Radiolaria. In The Fossil record-A symposium with documentation, ed. W.B. Harland, C.H. Holland, M.R. House, N.F. Hughes, A.B. Reynolds, M.J.S. Rudwick, G.E. Satterthwaite, L.B.H. Tarlo, and E.C. Willey, 291298. Cambridge: Geological Society of London.

Robinson, B.E. 1988. Upper Triassic radiolarian biostratigraphy of the Glenn Shale, east-central Alaska. Ph.D. thesis, University of Texas at Dallas, $171 \mathrm{p}$.

Sashida, K., H. Nishimura, H. Igo, S. Kazama, and Y. Kamata. 1993. Triassic radiolarian faunas from Kiso-fukushima, Kiso Mountains, central Japan. Science Reports of the Institute of Geoscience, University of Tsukuba, Sec. B (Geological Sciences) 14: 77-97.

Sugiyama, K. 1997. Triassic and Lower Jurassic radiolarian biostratigraphy in the siliceous claystone and bedded chert units of the southeastern Mino Terrane, Central Japan. Bulletin of the Mizunami Fossil Museum 24: 79-193.

Takemura, A. 1986. Classification of Jurassic Nassellarians (Radiolaria). Palaeontographica, Abteilung A: Paläozoologie. Stratigraphie 195(1-3): 29-74.

Tekin, U.K. 1999. Biostratigraphy and systematics of late middle to late Triassic radiolarians from the Taurus Mountains and Ankara Region, Turkey. Geologisch-Paläontologische Mitteilungen Innsbruck 5: 1-297.

Tekin, U.K., and Y. Bedi. 2007a. Ruesticyrtiidae (Radiolaria) from the middle Carnian (Late Triassic) of Köseyahya Nappe (Elbistan, eastern Turkey). Geologica Carpathica 58(2): 153167.

Tekin, U.K., and Y. Bedi. 2007b. Middle Carnian (Late Triassic) Nassellaria (Radiolaria) of Köseyahya Nappe from eastern Taurides, eastern Turkey. Rivista Italiana di Paleontologia $e$ Stratigrafia 113(2): 167-190.

Wang, Y., Q. Yang, A. Matsuoka, K. Kobayashi, T. Nagahashi, and Q. Zeng. 2002a. Triassic radiolarians from the Yarlung Zangbo Suture zone in the Jinlu area, Zetang County, Southern Tibet. Acta Micropalaeontologica Sinica 19(3): 215-227.

Wang, Y., J. Wang, and F. Pei. 2002b. A late Triassic radiolarian fauna in the Dingqing ophiolite Belt, Xizang (Tibet). Acta Micropalaeontologica Sinica 19(4): 323-336.

Yao, A. 1997. Faunal change of early-Middle Jurassic radiolarians. In Proceedings of the fifth Radiolarian symposium, ed. Yao, A., 155-182. News of Osaka Micropaleontologists, Special volume 10. 